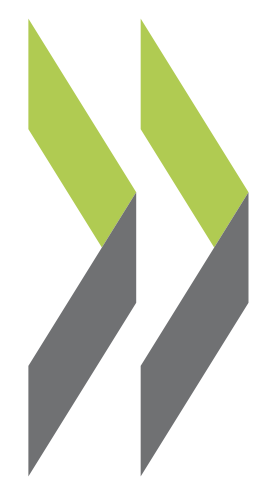

OECD Economics Department Working Papers No. 1175

Making Economic Growth more Socially Inclusive in Germany Andreas Kappeler, Andrés Fuentes Hutfilter 
Organisation de Coopération et de Développement Économiques

Organisation for Economic Co-operation and Development

01-Dec-2014

ECONOMICS DEPARTMENT

English - Or. English

\section{MAKING ECONOMIC GROWTH MORE SOCIALLY INCLUSIVE IN GERMANY}

ECONOMICS DEPARTMENT WORKING PAPERS No. 1175

By Andreas Kappeler and Andrés Fuentes Hutfilter

OECD Working Papers should not be reported as representing the official views of the OECD or of its member countries. The opinions expressed and arguments employed are those of the author(s).

Authorised for publication by Robert Ford, Deputy Director, Country Studies Branch, Economics Department.

All Economics Department Working Papers are available through OECD's Internet website at www.oecd.org/eco/Workingpapers

JT03367592

Complete document available on OLIS in its original format

This document and any map included herein are without prejudice to the status of or sovereignty over any territory, to the delimitation of international frontiers and boundaries and to the name of any territory, city or area. 
OECD Working Papers should not be reported as representing the official views of the OECD or of its member countries. The opinions expressed and arguments employed are those of the author(s).

Working Papers describe preliminary results or research in progress by the author(s) and are published to stimulate discussion on a broad range of issues on which the OECD works.

Comments on Working Papers are welcomed, and may be sent to the Economics Department, OECD, 2 rue André-Pascal, 75775 Paris Cedex 16, France, or by e-mail to eco.contact@oecd.org

This document and any map included herein are without prejudice to the status of or sovereignty over any territory, to the delimitation of international frontiers and boundaries and to the name of any territory, city or area.

The statistical data for Israel are supplied by and under the responsibility of the relevant Israeli authorities. The use of such data by the OECD is without prejudice to the status of the Golan Heights, East Jerusalem and Israeli settlements in the West Bank under the terms of international law.

\section{(C) OECD (2014)}

You can copy, download or print OECD content for your own use, and you can include excerpts from OECD publications, databases and multimedia products in your own documents, presentations, blogs, websites and teaching materials, provided that suitable acknowledgment of OECD as source and copyright owner is given. All requests for commercial use and translation rights should be submitted to rights@oecd.org 
ECO/WKP(2014)71

\section{Abstract/Résumé \\ Making Economic Growth more Socially Inclusive in Germany}

While past labour market reforms have been successful in terms of employment, the relative poverty risk and income inequality have remained broadly unchanged in recent years. Some social groups remain particularly vulnerable, including individuals in non-regular employment, the unemployed and the low skilled. If in employment, their jobs tend to be unstable and wages and income mobility low. Continued efforts are needed to foster economic growth in a more inclusive manner, such that the most vulnerable groups benefit from and contribute to economic growth more strongly and such that the gaps between the rich and the poor in terms of income and wellbeing are reduced. These efforts should include enhancing the labour market outcomes of the most vulnerable and increase upward income mobility among disadvantaged individuals; strengthening skills at the lower end of the skills distribution; revising the tax and benefit system to improve incentives and to ensure efficient and well-targeted redistribution; and to make health and old-age pension insurance more inclusive. This working paper relates to the 2014 OECD Economic Survey of Germany (http://www.oecd.org/eco/surveys/economic-survey-germany.htm).

JEL Classification: I24, I32, O52

Key words: Germany, inclusive growth, income inequality, labour markets, education, health, old age poverty, taxation.

$* * * * * * * * * *$

\section{Rendre la croissance économique plus inclusive en Allemagne}

Alors que les réformes du marché du travail opérées dans le passé ont été bénéfiques en termes d'emploi, le risque de pauvreté relative et les inégalités de revenus n'ont quasiment pas changé ces dernières années. Certains groupes sociaux restent particulièrement vulnérables, notamment les personnes ayant un emploi précaire, les chômeurs et les personnes peu qualifiées. Lorsque les personnes concernées ont un travail, il s'agit généralement d'emplois peu stables, et les salaires sont bas et la mobilité salariale faible. Il est nécessaire de poursuivre les efforts, pour faire en sorte que les groupes les plus vulnérables puissent bénéficier d'une croissance économique plus vigoureuse et y contribuer, pour accroître la mobilité à la hausse des revenus parmi les personnes défavorisées et pour atténuer les inégalités. L'accent devrait être mis sur les instruments de l'action publique permettant à la fois de réduire les inégalités de revenus et de doper la croissance du PIB. Il s'agit notamment d'améliorer le devenir professionnel des plus vulnérables; de renforcer les compétences au bas de l'échelle de distribution des compétences; de réviser le système de prélèvements et de prestations pour améliorer les incitations; et assurer une redistribution efficiente et bien ciblée; et rendre l'assurance santé et l'assurance retraite plus inclusives. Ce document de travail se rapporte à l'Étude économique de l'OCDE de l'Allemagne 2014 (http://www.oecd.org/fr/eco/etudes/etudeeconomique-allemagne.htm).

Mots-clés : I24, I32, O52

Classification JEL : Allemagne, croissance inclusive, marché du travail, enseignement, santé, pauvreté des personnes âgées, imposition. 


\section{TABLE OF CONTENTS}

MAKING ECONOMIC GROWTH MORE SOCIALLY INCLUSIVE IN GERMANY ...........................6

Strong labour market performance has had little impact on relative poverty risks and inequality

Inequality is marked in market incomes, wealth and well-being indicators .......................................

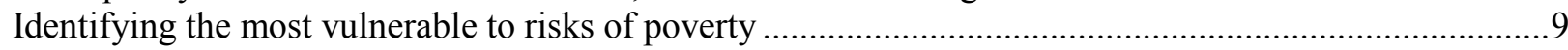

The low wage sector is large and includes many low skill workers ...................................................11

Workers in non-regular employment are exposed to high poverty risks............................................11

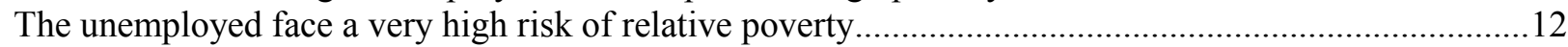

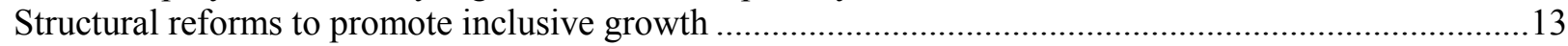

Reducing market income inequality through labour market reforms ....................................................14

Removing barriers to full-time employment would reduce poverty risks .............................................14

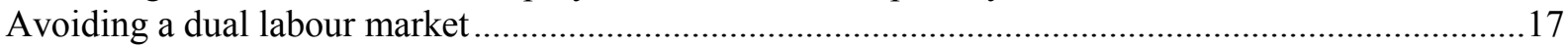

A minimum wage consistent with preserving employment ...............................................................18

Active labour market policies and in-work benefits could be improved...............................................19

The education system could provide more support for the disadvantaged ..........................................21

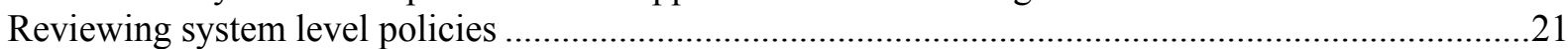

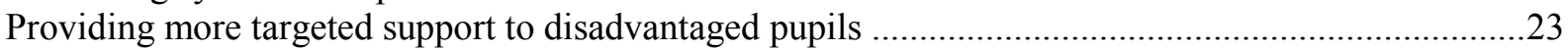

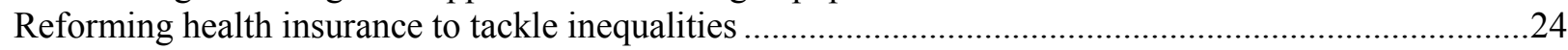

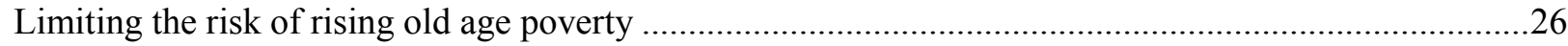

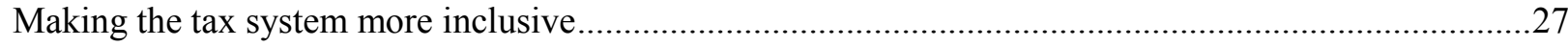

Regional pockets of poverty risk could be addressed more effectively ..................................................28

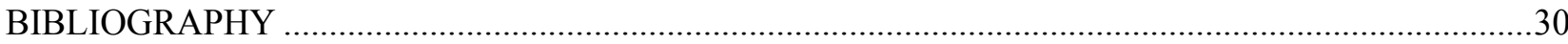

\section{Tables}

1. Exposure to poverty of workers in non-regular, part-time and self-employment ................................12

2. The impact of structural reforms on inequality and GDP per capita .............................................14

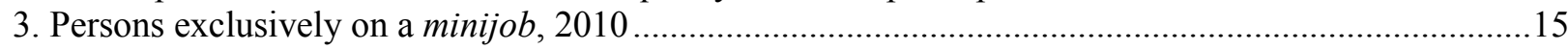

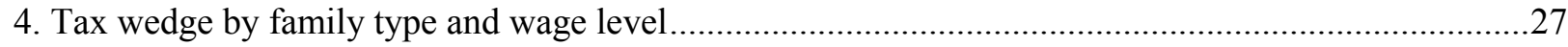

\section{Figures}

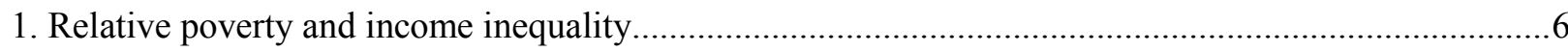

2. Effect of net taxes and transfers on income inequality ...................................................................

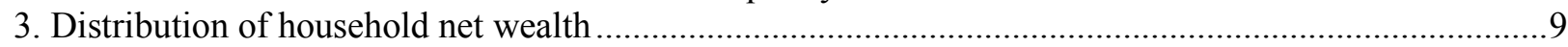

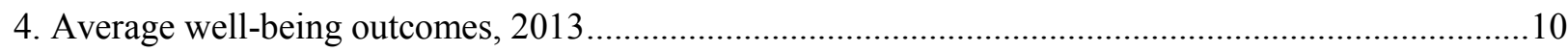

5. Low-wage earners by educational attainment level, employment contract and gender.........................11

6. Long-term unemployment by demographic group and education ................................................13

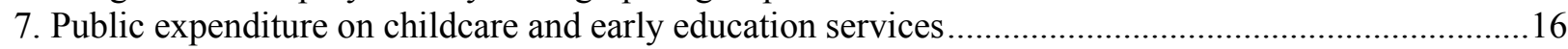

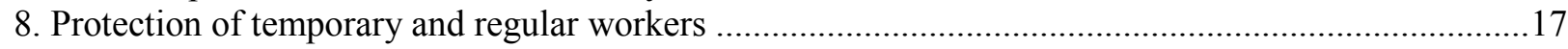

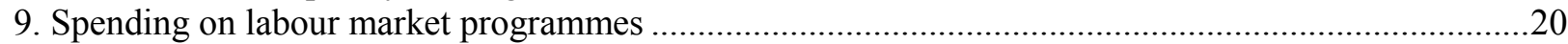

10. Impact of socio-economic status on the average difference in performance

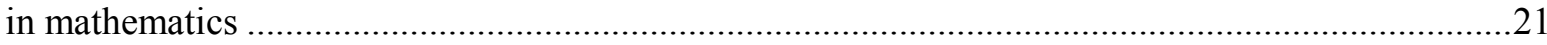

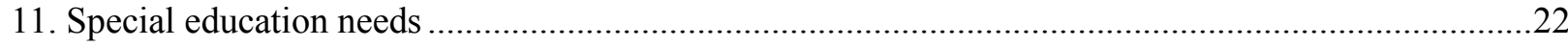


ECO/WKP(2014)71

\section{Boxes}

1. Determinants of rising income inequality and risk of relative poverty .................................................

2. Policy instruments and their impact on inequality and economic growth ...........................................14

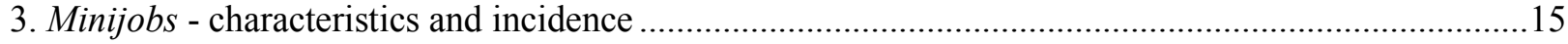

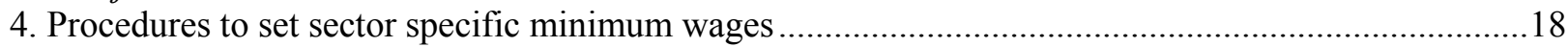

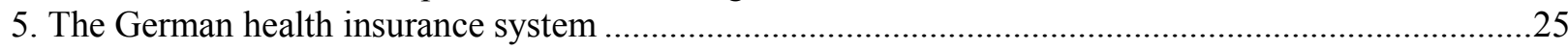

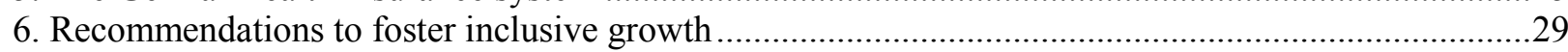




\section{MAKING ECONOMIC GROWTH MORE SOCIALLY INCLUSIVE IN GERMANY}

\section{By Andreas Kappeler and Andrés Fuentes Hutfilter ${ }^{1}$}

\section{Strong labour market performance has had little impact on relative poverty risks and inequality}

1. Inequality and relative poverty in Germany are below levels observed in many OECD countries They have risen since the mid-90s, as elsewhere, although income inequality has not increased since 2004 (Figure 1, bottom panel). GDP growth has benefited households with high incomes more than those with low incomes since the mid-1990s. The ratio of the top $10 \%$ to bottom $10 \%$ of disposable incomes has increased more than in many other OECD economies, especially before 2005 . Relative poverty increased particularly in East Germany, affecting $20 \%$ in 2009, which is almost twice as much as in the West. While real disposable household income inequality in East and West Germany did not converge much in the early 2000s, some convergence has occurred since 2005 (Grabka et al., 2012).

Figure 1. Relative poverty ${ }^{1}$ and income inequality ${ }^{2}$

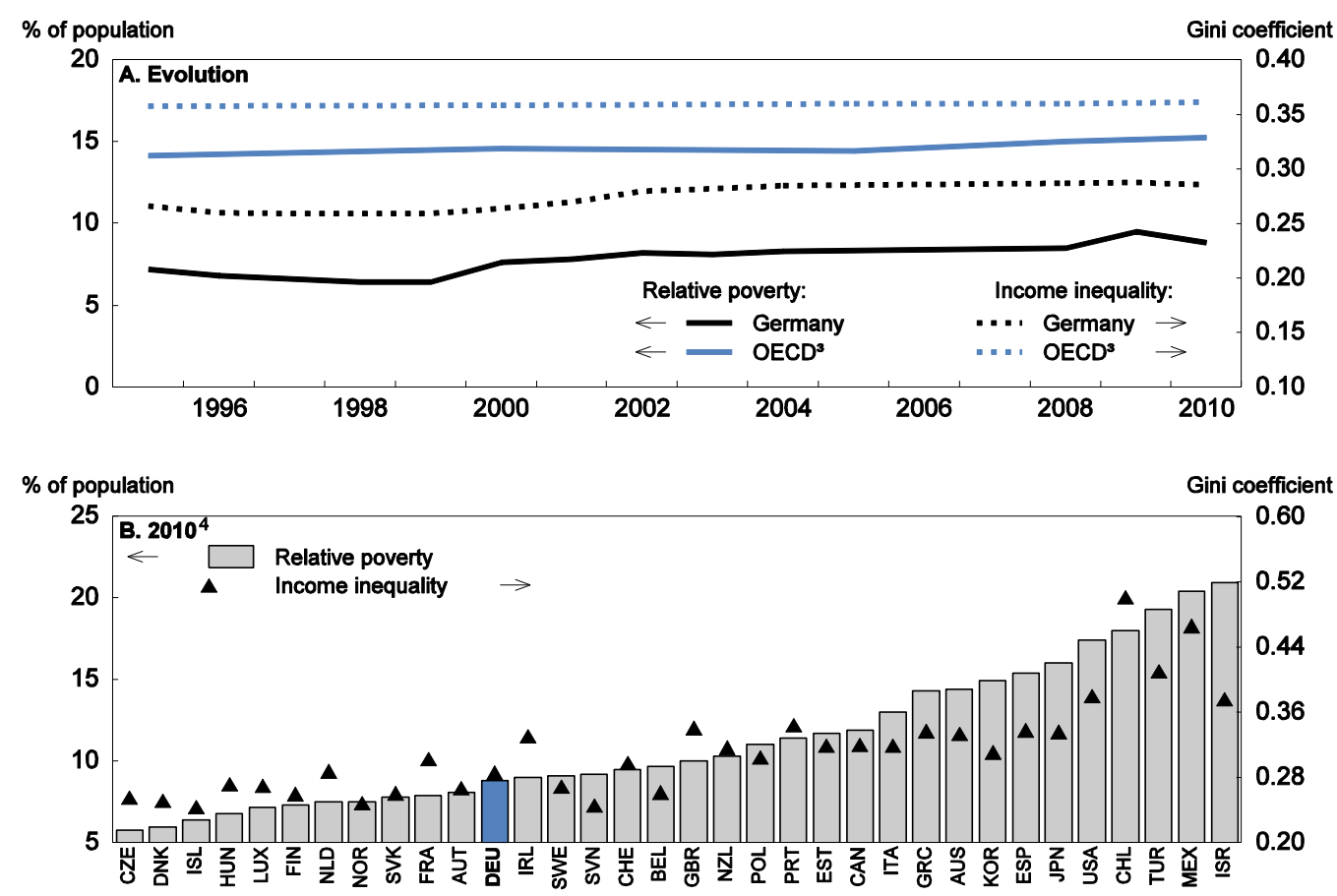

1. Relative poverty is measured as the percentage of the population whose equivalised household disposable income (after taxes and transfers) is below $50 \%$ of the median income.

2. Income inequality is measured as the Gini coefficient using household disposable income. It ranges from zero (perfect equality) to one (where one individual receives all).

3. Population-weighted average for 20 countries.

4. 2011 for Chile; 2009 for Hungary, Ireland, Japan, New Zealand, Switzerland and Turkey.

Source: OECD Income Distribution and Poverty database.

1. Andrés Fuentes Hutfilter is head of the Estonia/Germany Desk in the Economics Department of the OECD and Andreas Kappeler is an economist on that Desk. This paper is based on material prepared for the OECD Economic Survey of Germany published in May 2014 under the authority of the Economic and Development Review Committee (EDRC). The authors would like to thank Andrew Dean, Robert Ford, Andreas Wörgötter, André Eid, Monika Queisser and Juliana Zapata for valuable comments on earlier drafts. Special thanks go to Seung-Hee Koh for technical assistance and to Josiane Gutierrez and Heloise Wickramanayake for technical preparation. 
2. Thanks to the robust labour market, and in stark contrast to many other European countries, German household income has increased since 2007, benefitting incomes at both ends of the scale (OECD, 2012 and 2013a). Nevertheless, despite sustained employment growth and a significant drop in unemployment, largely brought about by far-reaching labour market reforms in the mid-2000s (OECD, 2012a), income inequality has not declined markedly over this period, either in absolute terms or relative to developments in OECD countries on average. The risk of relative poverty has, if anything, increased (OECD, 2013a). Kierzenkowski and Koske (2012) have identified a number of determinants of income inequality, some of them being particularly relevant for Germany (Box 1).

\section{Box 1. Determinants of rising income inequality and risk of relative poverty}

Skill-biased technological change: In many OECD countries, labour markets have become polarised, with computer technology depressing the middle of the wage and employment distributions where workers perform skilled but routine tasks, which leads to an increase in income inequality at the top end and a decrease at the low end. This pattern also appears in Germany (Dustmann et al., 2009; Spitz-Oener, 2006).

Education: Wage inequality is negatively correlated with the average level of educational attainment. In Germany returns to education have been broadly stable over time (Prasad, 2004; OECD, 2013d). Higher educational attainment is also positively correlated with well-being, in part because of more rewarding jobs.

International trade: Globalisation seems to have important implications for at least some groups of workers. In particular, offshoring appears to reduce employment and wages of medium-skilled workers performing routine tasks, thus reinforcing labour-market polarization.

Immigration: Immigration has a small impact on native workers and sizeable adverse wage or employment effects on the cohorts of previous immigrants are found for Germany, implying only small effects for overall labour income inequality (D'Amuri et al., 2010; Steinhardt, 2011).

Labour market regulation: It has been relaxed over the past 20 to 25 years in many OECD countries. The impact of declining unionisation and of the lower relative minimum wage, observed in many countries, is most pronounced at the lower end of the wage distribution. However, many such institutions (e.g. employment protection legislation, minimum wage) have opposite effects on employment and wage dispersion leaving the final impact on inequality undetermined (OECD, 2011). For Germany, there is little evidence that the labour market reforms in the mid-2000s have raised inequality.

Household structure: Changes in the household structure, driven by a tendency towards more single households, are an important trigger for poverty at the microeconomic level (OECD, 2008a). Among others, the labour market reforms in the mid-2000s have generated incentives for subsistence payment beneficiaries to form single-households (Peichl et al., 2010). The formation of smaller households due to separation is likely to affect spouses with low earnings and their children most.

\section{Inequality is marked in market incomes, wealth and well-being indicators}

3. Inequality in market incomes is higher than in many other OECD economies (Figure 2). The long-term increase in inequality of market incomes has been driven by rising disparities in labour incomes, and a particularly uneven distribution of self-employment incomes (OECD, 2012b). However, taxes and cash transfers play a larger role in mitigating market income inequality and risk of relative poverty than in most other countries. According to most recent data, the German tax-benefit system reduces inequality among the working-age population by almost $30 \%$. 
Figure 2. Effect of net taxes and transfers on income ${ }^{1}$ inequality $^{2}$

Gini coefficient, $2010^{3}$

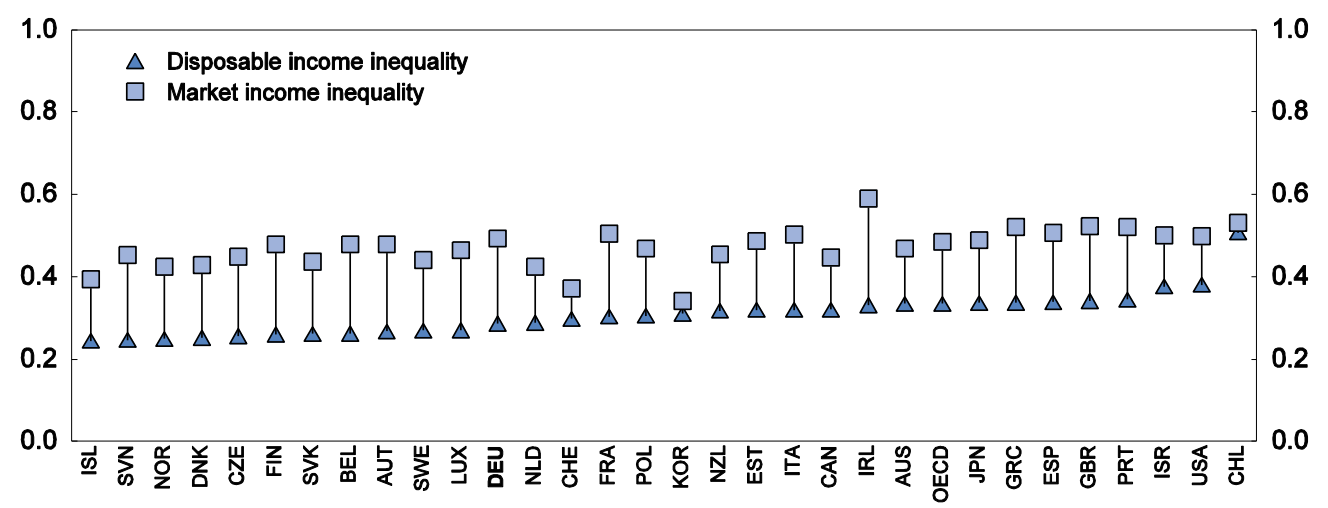

1. Income refers to cash income excluding imputed components such as home production and imputed rents regularly received over the year. Market income (i.e. before taxes and transfers) includes earnings (broken down into those of the household head, of the spouse and of other household members); self-employment income; and capital income (rents, dividends and interest).

2. Income inequality is measured as Gini coefficient for equivalised household market income and disposable income for the total population. It ranges from zero (perfect equality) to one (where one individual receives all).

3. 2011 for Chile; 2009 for Ireland, Japan, Switzerland and New Zealand. Market income Gini coefficient is not available for Hungary, Mexico and Turkey. The OECD average is calculated as a population-weighted average of 26 countries available for 2010.

Source: OECD Income Distribution and Poverty database.

4. Besides income inequality at any given point in time, the likelihood of an individual to move up or down the income distribution (income mobility, often measured in moves across quintiles) also matters for life-time inequality. Workless and low-income households suffer particularly from low upward income mobility as it raises the likelihood of long-lasting or repeated spells of poverty (OECD, 2008a) and prevents them from benefiting from and contributing to more economic growth. It is therefore worrisome that equivalised disposable income mobility has declined particularly for low income households since the late 1990s (German Council of Economic Experts, 2011 and 2013), with income mobility being especially low in East Germany. Wage mobility also steadily declined between 1976 and 2008 (Aretz, 2013), raising the risk of relative poverty for workers in the low wage sector. Changes in job stability and employment characteristics, including unemployment history, tenure and type of industry, explain a significant share of this decline (Riphahn and Schnitzlein, 2011).

5. In-kind benefits paid for by governments, notably health and education services have an important redistributive effect, but they are not reflected in the monetary measures of income inequality and risk of relative poverty. Although government spending on in-kind benefits is comparatively high as a share of GDP, its redistributive effect is estimated to be relatively small, which may suggest poor targeting (OECD, 2011; Verbist et al., 2012; Adema et al., 2011).

Wealth is less evenly distributed than income and has become more uneven (German Council of Economic Experts, 2009). It is also less evenly distributed across households than in other European economies (Figure 3). At 37\%, the share of households without any property or wealth is comparatively large. The $10 \%$ wealthiest households earn $31 \%$ of gross incomes and own $59 \%$ of net wealth (Deutsche Bundesbank, 2013). 
Figure 3. Distribution of household net wealth ${ }^{1}$

Ratio of top to bottom quintile, $2009^{2}$

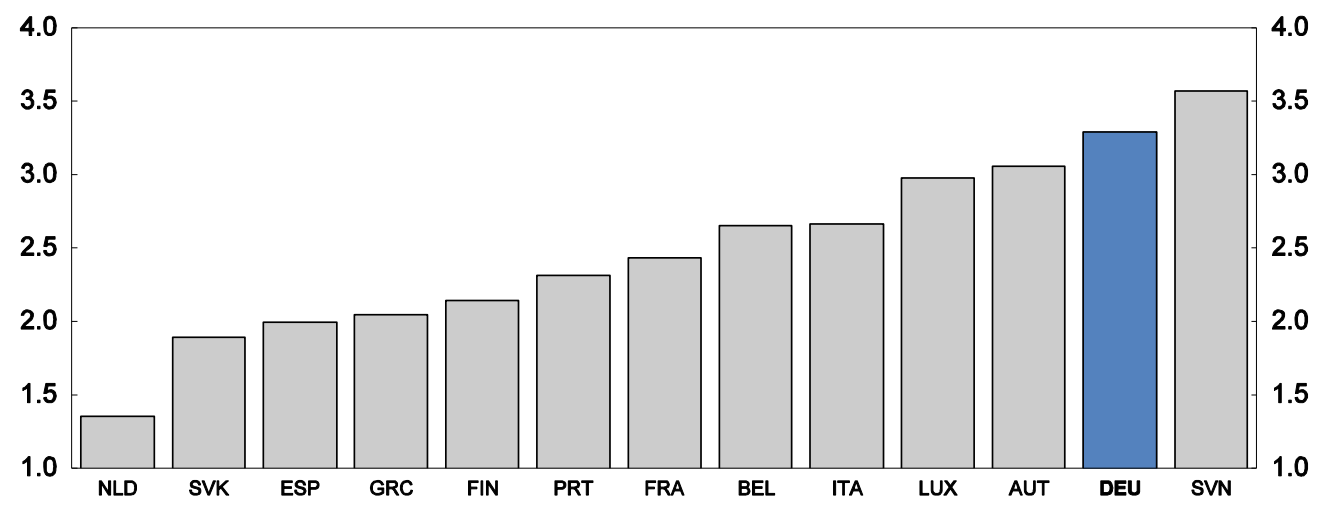

1. Net wealth is the difference between total household assets and total household liabilities.

2010 for Italy; 2007 for Spain.

Source: European Central Bank (2013), "The Eurosystem Household Finance and Consumption Survey - Statistical Tables", April.

6. A relatively large number of small households in Germany may account to some extent for the larger share of households with low wealth. Home ownership, which is the most important component of household net wealth, is highly concentrated among the wealthiest (Deutsche Bundesbank, 2013; Andrews and Caldera Sánchez, 2011). The tax regime may have encouraged wealthy households to invest in residential real estate (see below). The divergence of wealth between East and West Germany also contributes to the uneven distribution of wealth (Frick and Grabka, 2009).

7. According to the OECD well-being framework, which encompasses eleven domains covering both material and non-material living conditions, German households enjoy a relatively high level of economic welfare and perform well in most domains (OECD, 2013g). However, well-being outcomes for individuals with high income/high education are considerably better than for individuals with low income/low education in several domains. For instance, individuals with high income report a considerably better health status than individuals with low income. The strong impact of socio-economic background on education attainment also points towards inequalities in well-being outcomes (Figure 4). Moreover, 25\% of individuals live in households where the total housing costs - net of housing allowances - represent $40 \%$ or more of their disposable income (10\% OECD wide; OECD, 2013g).

\section{Identifying the most vulnerable to risks of poverty}

8. Some social groups - including low skilled, individuals in non-regular employment and unemployed - are particularly vulnerable. They face a high risk of relative poverty and, if in employment, their jobs tend to be unstable, their wages low and their income mobility subdued. 
Figure 4. Average well-being outcomes, 2013

\section{A. Population with high income or education}

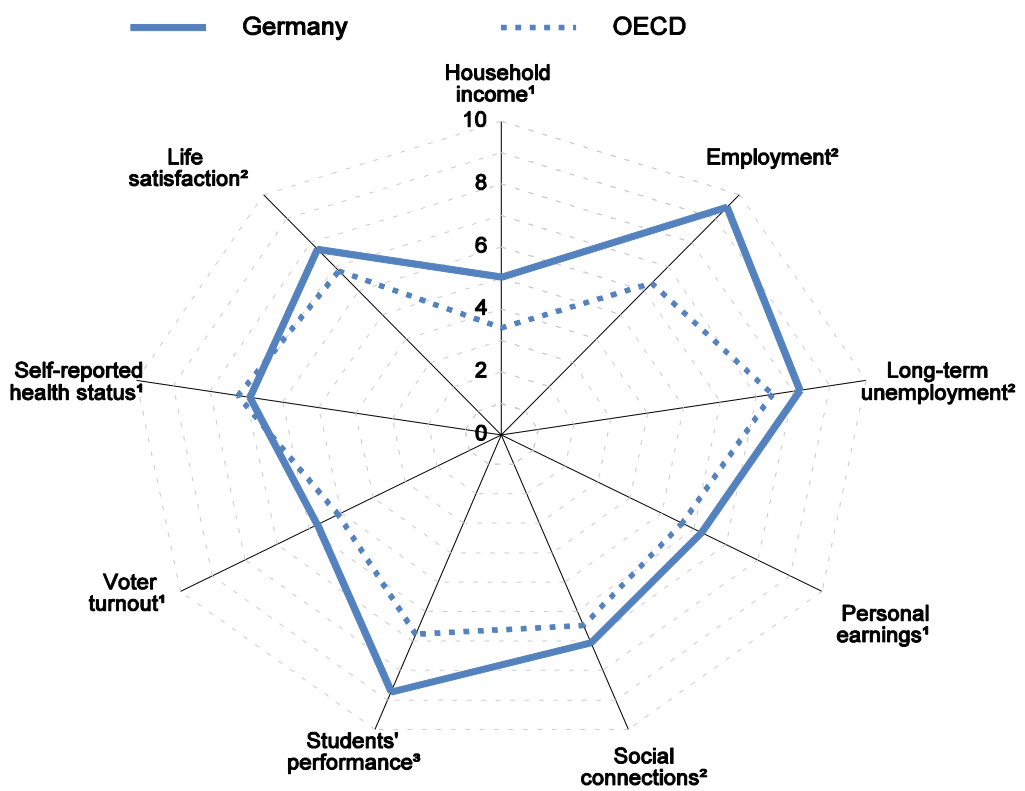

B. Population with low income or education

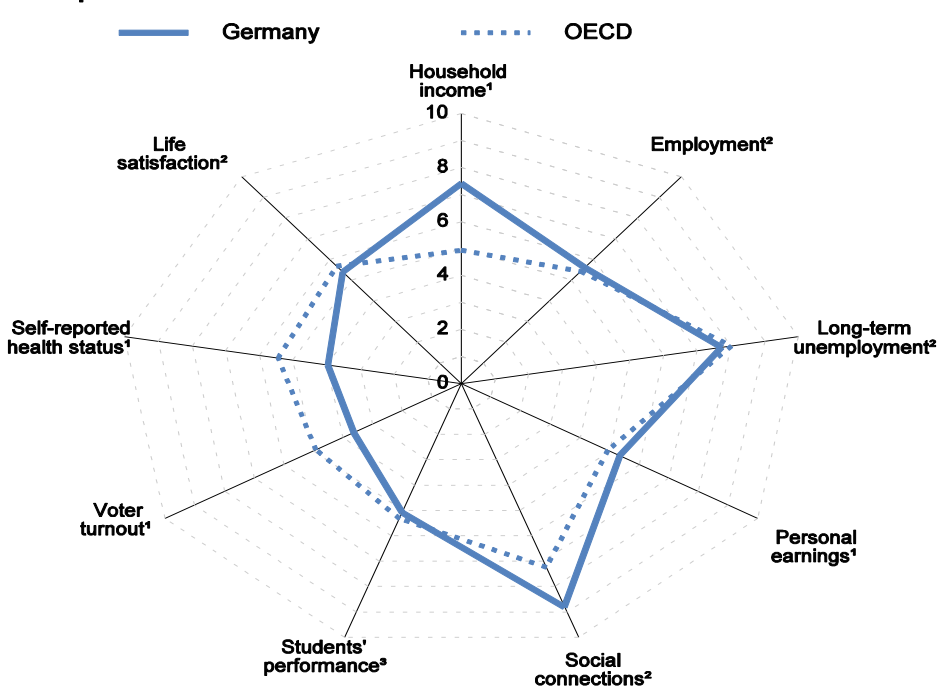

Note: Indicators are normalized to range between 10 (best) and 0 according to the following formula: (indicator value - minimum value) / (maximum value - minimum value) multiplied by 10.

Panel A:

1. Adult population in the top income or earnings quintile.

2. Adult population with a tertiary education degree (ISCED 5-6).

3. 15-year-old students in the top quintile of the PISA index of economic, social and cultural status.

Panel B:

1. Adult population in the bottom income or earnings quintile.

2. Adult population with at most a lower secondary education degree (ISCED 0-2).

3. 15-year-old students in the bottom quintile of the PISA index of economic, social and cultural status.

Source: OECD Better Life Index. 


\section{The low wage sector is large and includes many low skill workers}

9. Low-wage employment increased between 2006 and 2010 and is particularly widespread among low skilled workers and women (Figure 5). While the share of low skilled individuals in the population is low, a relatively large share of low wage earners has low skills. This suggests that job matching is effective, but also that better targeted efforts to improve skills could considerably improve the income prospects of these workers. The large share of women in the low wage sector partly reflects the large gap between men and women in hourly wages. This may partly be due to more frequent and extended interruptions in working careers, a larger share of women who work part-time and differences in occupation (OECD, 2012h). The gender gap in full-time earnings is one of the largest among OECD countries. This is also true for the bottom quintile of full-time earners (OECD, 2013f).

Figure 5. Low-wage earners ${ }^{1}$ by educational attainment level ${ }^{2}$, employment contract and gender

As a percentage of employees ${ }^{3}, 2010$

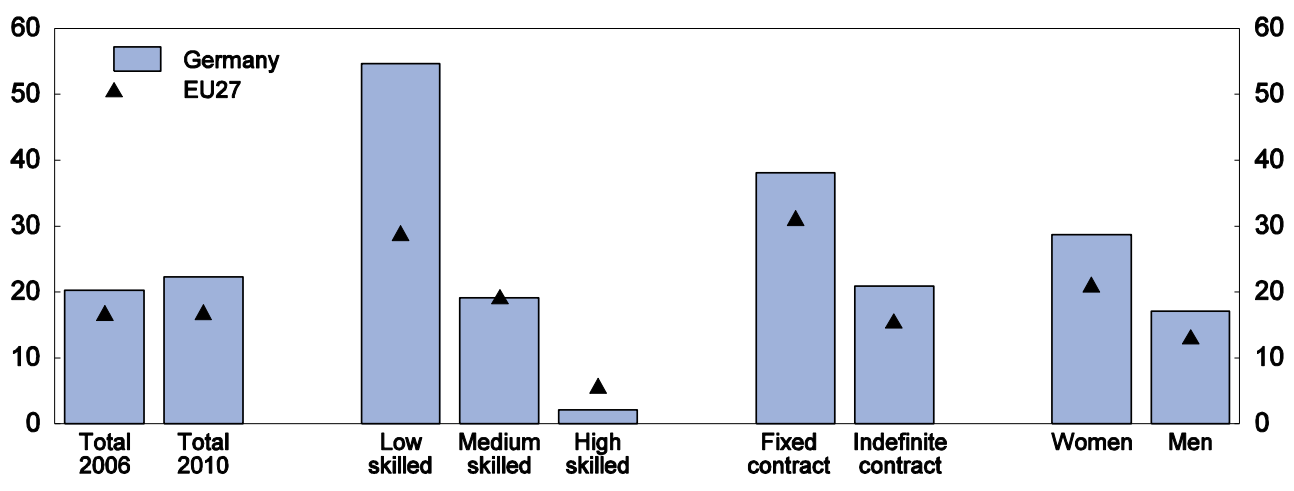

1. Low-wage earners are defined as those employees earning less than two thirds of the median gross hourly earnings.

2. Low skilled, medium skilled and high skilled are defined respectively as educational attainments of below upper secondary (ISCED 0-2), upper and post-secondary (ISCED 3-4) and tertiary (ISCED 5-6).

3. All employees excluding apprentices working in enterprises with more than 10 employees and which operate in all sectors of the economy except agriculture, forestry and fishing (NACE Rev. 2 section A); and public administration, defence and compulsory social security (NACE Rev. 2 section O).

Source: Eurostat.

\section{Workers in non-regular employment are exposed to high poverty risks}

10. While past labour market reforms have put more workers into jobs, poverty risks are high for workers in non-regular employment (defined here as employees with relatively low employment protection or limited access to unemployment insurance), as well as many part-time and self-employed workers, especially those without employees (Table 1). As in other OECD countries, such workers are often paid low wages, suffer from low wage mobility and are less well protected than workers on permanent contracts (OECD, 2012a). 
Table 1. Exposure to poverty of workers in non-regular, part-time and self-employment

\begin{tabular}{|c|c|c|c|c|c|}
\hline & \multicolumn{2}{|c|}{ Risk of poverty } & \multicolumn{3}{|c|}{ Share of total workers (in \%) } \\
\hline & 1998 & 2008 & 1998 & 2008 & 2011 \\
\hline Total employment & 4.6 & 6.2 & 100.0 & 100.0 & 100.0 \\
\hline Dependent & 4.4 & 6.0 & 89.6 & 88.4 & 88.7 \\
\hline $\begin{array}{l}\text { Dependent permanent full- } \\
\text { time }\end{array}$ & 3.1 & 3.2 & 73.2 & 66.1 & 66.5 \\
\hline \multicolumn{6}{|l|}{ Dependent non-regular } \\
\hline Temporary & 10.8 & 16.5 & 5.8 & 7.9 & 7.9 \\
\hline Marginal (minijobs) & 13.0 & 23.2 & 4.7 & 7.4 & 7.5 \\
\hline Temporary agency & & 8.5 & & 1.8 & 2.2 \\
\hline Part-time & 9.9 & 15.3 & 10.9 & 14.1 & 14.1 \\
\hline Self-employed & 6.7 & 7.7 & 10.4 & 11.6 & 11.3 \\
\hline $\begin{array}{l}\text { Self-employed without } \\
\text { employees }\end{array}$ & 9.3 & 10.3 & 5.1 & 6.5 & 6.3 \\
\hline
\end{tabular}

Note: The table refers to individuals aged 15-64, not in education or training. The risk of relative poverty is assessed on the basis of the mean equivalised disposable household income, at the $60 \%$ threshold. Non-regular employment consists here of temporary employees, workers in marginal employment (minijobs) and temporary agency workers. Overlaps among the different forms of nonregular employment and part-time employment exist.

Source: Federal Statistical Office of Germany.

11. Part-time work is particularly widespread among women: only $62 \%$ of employed women work full-time compared to 74\% OECD-wide in 2012. Part-time work is characterised by a high risk of relative poverty. Also, their prospects of moving to full-time, permanent employment are often limited. They often face unstable employment, they tend to receive less in-work training and have poor chances to move up the income ladder. A considerable number of vulnerable part-timers is in marginal employment (minijobs, see Box 3 below). These vulnerabilities are attenuated to some extent at the household level, as many part-time workers are secondary earners. Nonetheless, even for secondary earners in high-income households parttime employment may entail the risk of falling into relative poverty in the future, for example in the case of changes in the household, possibly as a result of separation.

12. The number of workers in employment receiving top-up subsistence benefits increased to $3 \%$ of total employment in 2011. Most are in marginal employment and $18 \%$ are single parents (Bruckmeier et al., 2013). Some $44 \%$ of individuals receiving subsistence payments who find a job continue to depend on top-up benefits and $45 \%$ are in employment for 6 months or less, which may reduce their income mobility (Koller and Rudolph, 2011).

\section{The unemployed face a very high risk of relative poverty}

13. Many workers in non-regular employment acquire little or no unemployment insurance benefit entitlements, but face a high risk of unemployment. Lack of employment is particularly widespread among single parent households, which represent $5.9 \%$ of total households. Sixty-five per cent of single parents were in employment in 2008, less than in most other OECD countries, and labour market participation is particularly low for mothers with children aged 4 or less (Federal Ministry of Finance, 2012). Also individuals approaching retirement age are characterized by low employment and a high risk of relative poverty.

14. While long-term unemployment has decreased sharply in recent years, it continues to account for more than $40 \%$ of total unemployment. The long-term unemployed are particularly vulnerable to poverty risks, because longer unemployment spells reduce employability and workers lose their unemployment 
insurance benefit entitlement. Low skilled workers are more likely to face long-term unemployment (Figure 6). Also older works face a high risk of long-term unemployment which, unlike for youth and prime-age individuals, is close to the EU average. The high incidence of long-term unemployment among older workers, including those with medium vocational qualifications, suggests that older workers with a narrow set of skills have difficulties to adapt to structural changes in the economy that may occur during their working life.

Figure 6. Long-term unemployment ${ }^{1}$ by demographic group ${ }^{2}$ and education ${ }^{3}$

As a percentage of labour force, 2012Q4

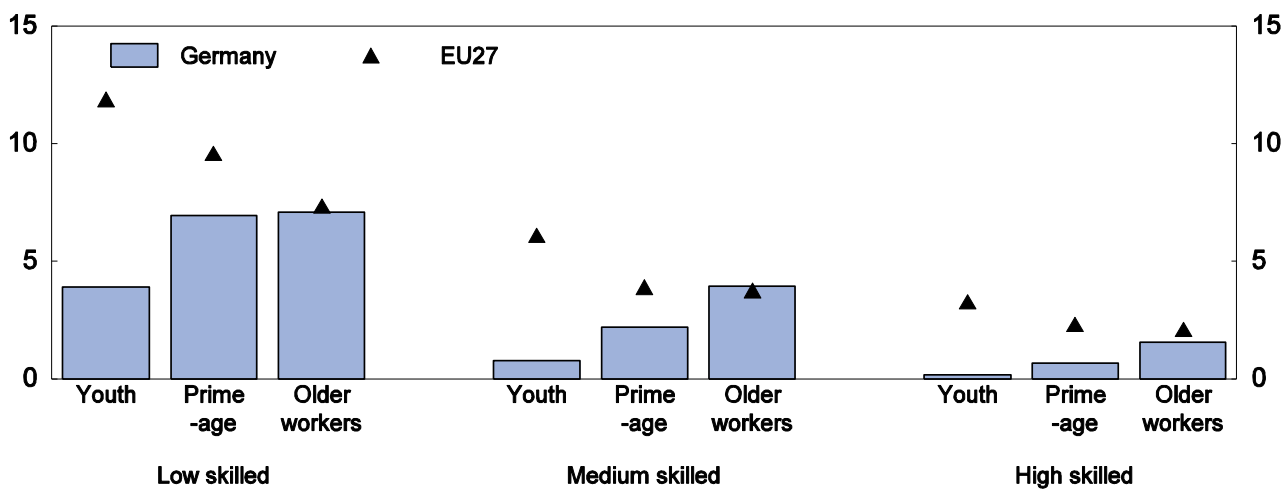

1. Unemployed for more than one year as a three-month moving average.

2. Youth, prime-age and old workers are defined respectively as persons aged 15-24, 25-54 and 55-64 years.

3. Statistics by education refer to persons aged 15-64 years. Low skilled, medium skilled and high skilled are defined respectively as educational attainments of below upper secondary (ISCED 0-2), upper and post-secondary (ISCED 3-4) and tertiary (ISCED $5-6)$.

Source: OECD (2013), Employment Outlook.

15. The risk of relative poverty for immigrants is almost twice as high as for German nationals, in part because unemployment among immigrants is about twice as high. Moreover, the incidence of long-term unemployment is high, also in international comparison (OECD, 2012f). The high share of the low skilled among immigrants reduces their wages and employability (Koske et al., 2012). To some extent this is also true among second generation immigrants indicating the need to make integration policies more effective.

\section{Structural reforms to promote inclusive growth}

16. Continued efforts are needed to foster economic growth in a more inclusive manner, such that the most vulnerable groups benefit from and contribute to economic growth more strongly and such that the gaps between the rich and the poor in terms of income and wellbeing are reduced. As discussed below, more inclusive growth requires enhancing the labour market outcomes of the most vulnerable and improving skills at the lower end of the skills distribution, as well as reforms of the tax and benefit system to ensure efficient and well-targeted redistribution. The focus should be on policy instruments which entail a double dividend by reducing income inequality and boosting GDP growth at the same time. Going for Growth 2012 has benchmarked a number of policy instruments against these two objectives (Box 2; OECD, 2012g). 


\section{Box 2. Policy instruments and their impact on inequality and economic growth}

General policy trade-offs and complementarities between growth and income distribution objectives as identified in Going for Growth 2012 are summarized in Table 2.

- Policies which reduce income inequality and at the same time boost long-run GDP per capita include instruments to raise human capital while making it less dependent on personal and social circumstances, reducing labour market duality, promoting the integration of immigrants and fostering female labour market participation. Some tax policies, notably to reduce tax expenditures, contributes to equity objectives while also allowing a growth-friendly cut in effective marginal tax rates, in particular for lower income recipients.

- Several policies may entail a trade-off between reducing income inequality and raising GDP per capita. For instance, administrative extensions of collective wage agreements may reduce wage earnings dispersion among workers, but they may harm competition and productivity and possibly reduce employment. Shifting the tax mix to less-distorting taxes - in particular away from labour and corporate income taxes towards consumption, proper pricing of environmental externalities and real estate taxes - would improve incentives to work, save and invest, but may require additional steps to address adverse implications for equity.

Table 2. The impact of structural reforms on inequality and GDP per capita

\begin{tabular}{l|rrr}
\hline A rise in: & $\begin{array}{c}\text { Earnings } \\
\text { equality }\end{array}$ & $\begin{array}{c}\text { Total labour } \\
\text { income } \\
\text { equality }\end{array}$ & $\begin{array}{c}\text { GDP per } \\
\text { capita }\end{array}$ \\
\hline Initiatives to increase the tertiary graduation rate & + & $(+)$ & + \\
Initiatives to increase the upper-secondary graduation rate & + & $(+)$ & + \\
Initiatives to promote equity in education & + & + & $\sim$ \\
The minimum wage (as share of the median wage) & $\sim$ & $(-)$ & $(0 /-)$ \\
Legal extensions of collective wage agreements & + & - & - \\
The overall level of EPL & - & $(-)$ & - \\
The gap between EPL on regular versus temporary work & + & - & - \\
Replacement rate and duration of unemployment benefits & & + & + \\
Spending on active labour market policies & + & $(+)$ & $(+)$ \\
Initiatives to foster the integration of immigrants & + & $(+)$ & $(+)$ \\
\hline Initiatives to raise female labour force participation & + & + \\
\hline
\end{tabular}

Note: The term "earnings inequality" refers to inequality among the working population and the term "total labour income inequality" refers to inequality among the working-age population, thus accounting for both employment and earnings inequality effects.,,+- 0 denote respectively a significant rise, a significant fall, or no impact on the variable of interest. In cases where some studies find a significant effect while others don't, this is indicated by combining the symbols. A tilde means that the sign of the effect is unknown. When the sign of the total labour income inequality effect is unknown but can be deducted from the signs of the employment and earnings equality effects, the results are reported in brackets.

Source: Koske et al. (2012).

\section{Reducing market income inequality through labour market reforms}

17. There is scope to help the most vulnerable to improve their labour market outcomes, which would boost growth and at the same time address the uneven distribution of market incomes. Three reform areas deserve particular attention: avoiding low employment and low pay traps, avoiding a dual labour market and strengthening active labour market policies (ALMP).

\section{Removing barriers to full-time employment would reduce poverty risks}

18. Policies that discourage full-time employment should be carefully reviewed as they tend to reduce upwards income mobility of vulnerable individuals and growth. This section argues that the high incidence of part-time employment is favoured by the tax treatment of marginal employment and the 
limited supply of full-time childcare facilities, which also makes it difficult for families with children to fully participate in economic activity.

\section{Avoiding low employment and low pay traps}

19. Marginal employment (so-called minijobs) refers to low income employment contracts of up to EUR 450 per month, which benefit from tax subsidies, are partially exempt from the mandatory public pension system and fully exempt from unemployment insurance (Box 3). minijobs were intended as a stepping stone towards permanent full-time employment relationships but a success has not been proven. Reduced income tax and social security rates are phased out between EUR 450 and EUR 850 via so-called midijobs, thereby implying high marginal tax rates for individuals willing to work more (Freier and Steiner, 2007; Körner et al., 2013; Fertig and Kluve, 2007). Workers in minijobs tend to suffer from low in-work training opportunities and low wage mobility, locking them into their marginal employment status (Voss and Weinkopf, 2012). Some workers on minijobs are exposed to a rising risk of relative poverty once they retire or in case of losing their job (Hohendanner and Stegmaier, 2012) because they acquire low pension entitlements and are not entitled to unemployment insurance benefits. As the tax subsidy is not targeted to low income individuals, many minijobs are taken up by second earners to avoid high taxation in the context of the joint income taxation of couples. Minijobs also create an additional tax advantage for workers with more than one job, one of them being marginal employment, as income from other jobs does not count towards the minijob income ceiling. The number of individuals using marginal employment as side job has almost doubled since 2004 and accounted for 34\% of all individuals with a minijob in 2011 (Hohendanner and Stegmaier, 2012). Minijobs should be better targeted towards low-wage workers. For example, tax subsidies should not be provided for combining jobs, one of them being a minijob.

\section{Box 3. Minijobs - characteristics and incidence}

Minijobs refer to employment contracts for earnings of currently up to EUR 450 per month with reduced income tax and social security contribution rates and entitlements. Mandatory social security contribution rates amount to roughly $29 \%$, compared to $39 \%$ or more for permanent full-time employment. Unlike the case of permanent full-time employment, compulsory social security contributions are fully paid by employers. Since 2013 individuals can opt out of full pension coverage by not paying the employees' pension contribution rate of $3.9 \%$, on top of the employer's mandatory contribution of $15 \%$. In practice, this option leaves a considerably share of individuals in marginal employment with limited entitlement once they retire. Workers in marginal employment do not contribute to unemployment insurance and are not entitled to unemployment insurance benefits. They are subject to income tax at a flat-rate of $2 \%$. Many individuals in marginal employment, about 5.5 million in total, are students, pensioners or second earners (Table 3).

Table 3. Persons exclusively on a minijob, 2010

\begin{tabular}{l|r}
\hline & \multicolumn{1}{|c}{$\%$} \\
\hline Total & 100.0 \\
Students & 20.1 \\
Second earners & 35.2 \\
\hline Pensioners & 22.4 \\
Subsistence benefit receivers & 11.1 \\
Others & 11.2 \\
\hline
\end{tabular}

Source: Körner et al. (2013).

Midijobs, referring to earnings between EUR 450 and EUR 850, are subject to reduced social insurance contributions as well, but with rates increasing gradually to the standard rates. There were 1.37 million midijobs in 2011. 


\section{Further expansion of childcare to facilitate full-time employment}

20. Sufficient and affordable formal childcare facilitates the labour market integration of single parents and improves earnings prospects, especially for low income households (Rainer et al., 2011; Rainer et al., 2013). A lack of childcare facilities is of particular concern for single parents as they and their children are subject to high poverty risks in Germany (Zabel, 2011). Formal childcare also favours other family policy goals, such as increasing fertility and improving work-life balance.

Figure 7. Public expenditure on childcare and early education services

As a percentage of GDP, 2009

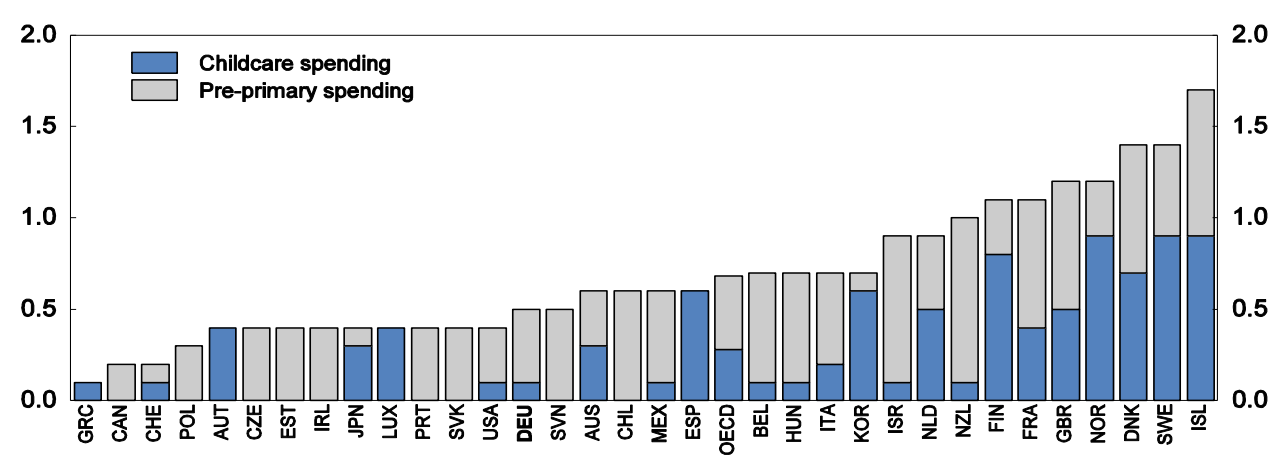

Note: Aggregate spending for Spain.

Source: OECD Family database.

21. Germany is making progress in expanding childcare and has guaranteed access for all parents, if only for a few hours per day. However, enrolment rates in early childcare (one-to-two-year-olds) remain low and access to full-time care is limited. One reason is comparatively low total public spending on childcare and early education (see Figure 7), although it has increased in recent years. Since August 2013 parents have a legal claim to public care for children aged one year or more. In practice, however, several conditions may prevent parents from enforcing this right. For instance they cannot reject offered places, even if they imply longer commuting distance. Moreover, the availability of full-time care remains limited, also for pupils more than 5 years old (Blossfeld et al., 2013; OECD, 2014). Efforts should continue to expand early childcare, notably full-time care and all-day school provision.

22. Attendance at formal childcare is particularly low among children from low income households or with a migrant background (Spieß et al., 2008; Blossfeld et al., 2013; Authoring Group Educational Reporting, 2013). While 33\% of children without migration background attend childcare at the age of zero to 3 years, only $16 \%$ of children with migration background do so (Federal Statistical Office, 2012). These households are often less informed about the benefits of formal childcare and may particularly be discouraged by high fees. However early childcare and childhood education is an important determinant of learning outcomes later on (Heckman and Masterov, 2007). The most seriously disadvantaged children reap particularly large cognitive and non-cognitive skill gains (Heckman and Raut, 2013). Children with migrant background also benefit by acquiring language through education (OECD, 2008a). Further efforts and resources are needed to raise the participation of children with weak socio-economic background in early childcare and early childhood education. Fees are set by municipalities and thus vary considerably across regions (Gathmann and Sass, 2012). Equal access to affordable high-quality childcare should be ensured independently of place of residence and socio-economic background. 


\section{Avoiding a dual labour market}

23. The gap between employment protection of permanent workers with long seniority and temporary workers is large in Germany (Figure 8). One reason is that Germany is the OECD country with the most far-reaching employment protection legislation for workers with open-ended contracts. A reform in 2011 tightened regulation of temporary agency workers and the 2013 coalition agreement spelled out plans to go somewhat further in this direction by requiring equal pay between in-house workers and temporary agency workers with equal tasks after 9 months. In contrast, the use of fixed-term contracts has been eased substantially since the late 1990s and regulation of temporary contracts is now among the least restrictive among OECD countries (Eichhorst and Tobsch, 2013). For example, it is under certain conditions possible to use multiple successive fixed-term contracts with the same employee (European Court of Justice, 2012), generating incentives to substitute regular work contracts with fixed-term contracts.

Figure 8. Protection of temporary and regular workers

Scale 0 (least restrictions) to 6 (most restrictions), 2013
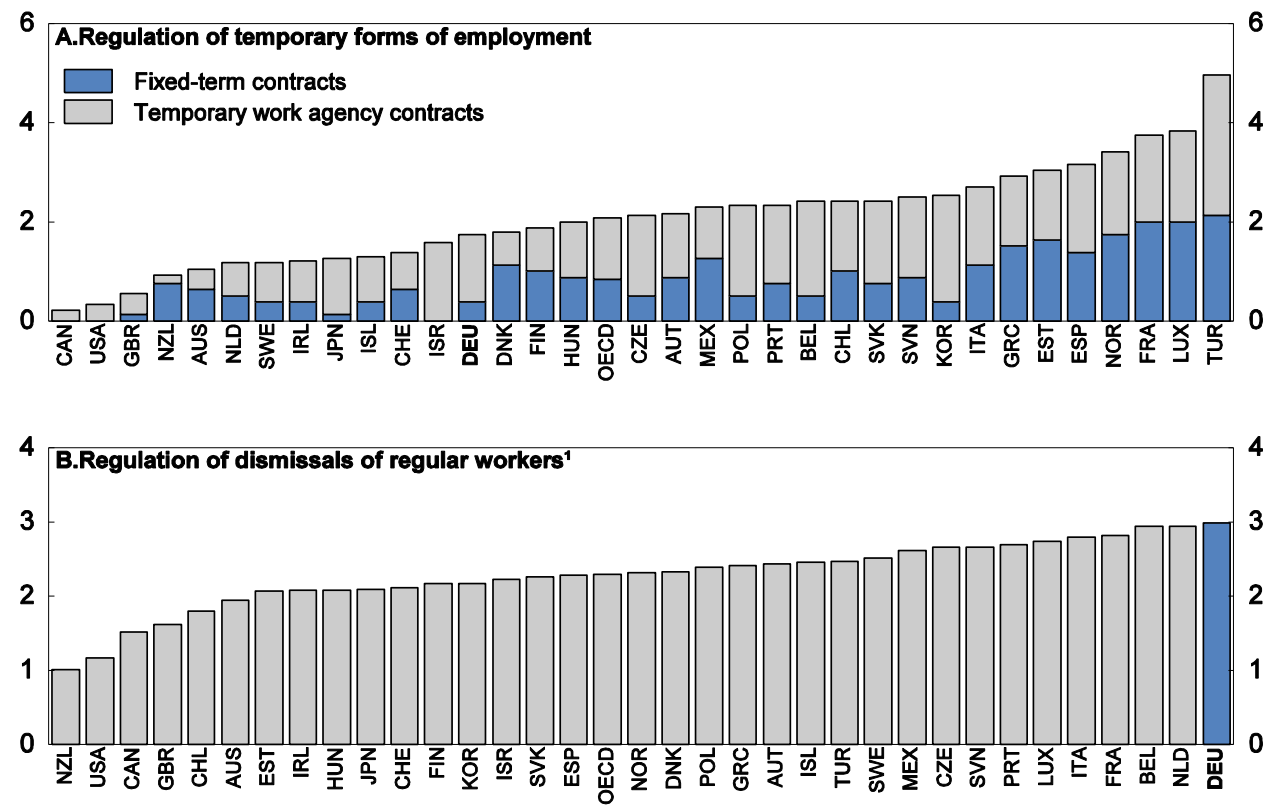

1. Aggregate contributions of employment protection for regular workers against individual dismissals and additional cost of collective dismissals.

Source: OECD (2013), Employment Outlook.

24. Permanent employment has contributed strongly to employment growth in Germany in recent years. Thirty nine per cent of workers on temporary contracts moved to a permanent contract within one year (Walwei, 2013). However, international evidence shows that a large gap in employment protection between permanent and temporary workers often tends to thwart employability (de Serres et al., 2012), increases inequality (Box 1) and hampers the transition from non-regular employment to permanent fulltime employment. It thereby also lowers wage mobility (Riphahn and Schnitzlein, 2011; Koske et al., 2012). Against this backdrop, the gap in employment protection between permanent and temporary workers should be reduced to further improve the transition of workers in temporary employment relationships into permanent jobs. The strict regulation of regular employment should be reviewed along 
the lines suggested in the 2012 Economic Survey of Germany. Simultaneously the regulation of fixed term contracts should be reviewed as well. In particular, the use of multiple successive fixed term contracts with the same employee should be limited in scope.

\section{A minimum wage consistent with preserving employment}

25. A minimum wage may be an effective instrument to reduce the dispersion of wages while preserving employment prospects (Garloff, 2010; Card and Krueger, 1995). It may also limit the need for benefit top-ups the government pays to low-wage recipients. Negative employment effects are less likely to occur when employers' bargaining power is high and workers' bargaining power is low (Koske et al., 2012). In such cases there is potential for redistribution of rents without reducing employment. For example, low wealth and low income (especially in the absence of unemployment benefit entitlement) can push job searchers to accept jobs paying below the marginal product in order to avoid the costs of continuing searching. Search models show that a minimum wage may even generate positive employment effects, as a minimum wage raises incentives for individuals to work and improve their skills (Acemoglu and Pischke, 2001; OECD, 2008b). The experience of the United Kingdom, which implemented a fairly low minimum wage relative to the median wage in 1999, but subsequently increased it substantially in several steps, shows that employment has not fallen due to the introduction of a nationwide minimum wage (OECD , 2004), and was also not affected by the increase in minimum wage during the recent economic and financial crisis (Bryan et al., 2012).

\section{Box 4. Procedures to set sector specific minimum wages}

There are two main procedures to implement a sector-specific minimum wage.

If (1) a minimum of $50 \%$ of employees are covered by collective agreements and (2) there is a public interest, a collective agreement can be declared as generally binding for all employees in the region and sector. To introduce such a sectoral and regional minimum wage, employers' associations and trade unions of the sector have to file a joint application for legal extension with the Federal Ministry of Labour and Social Affairs, specifying the agreed minimum wage. Once accepted by the Federal Ministry of Labour and Social Affairs, the agreement is binding for all employees and employers in the sector. If the government of a Land contests a proposal for legal extension, consent by the federal government is needed.

If less than $50 \%$ of all employees in a sector are employed by employers who are bound by collective agreements a permanent council can propose a sectoral minimum wage. The permanent council consists of two representatives of employers of the sectors concerned, two representatives of labour unions of the sectors concerned and three representatives from the Federal Ministry of Labour and Social Affairs. Alternatively, an expert commission, composed of three representatives of employers and three from labour unions, and, optionally, experts without voting rights, can propose a minimum wage, which can be introduced by the federal government.

Sectoral minimum wages are in place in several branches and occupations: construction and related crafts, (safety services, cleaning services, long-term care, vocational education and further training services and waste management). A minimum wage also exists for temporary agency workers. Sectoral minimum wages in Germany varied between EUR 7.50 per hour and EUR 13.70 per hour in 2013. Many of these minimum wages vary across regions.

26. Currently, a minimum wage can be set for individual sectors, which has been done in several cases in Germany, mostly on the basis of extending collectively bargained wages. Two procedures exist to set a sector specific minimum wage (see Box 4). The extension of collective wage agreements incurs the risk of harming employment prospects of "outsiders". For instance, legal extension of sectoral wage agreements can reduce incentives of social partners to set wages low enough for unemployed to have a reasonable chance of finding a job, as no employer can compete by reducing costs with a lower wage. 
Raising wages via the legal extension of collective wage agreements may also be a way for incumbents to prevent the entry of firms and thereby thwart competition and employment. Moreover, sectoral minimum wages can be circumvented by outsourcing activity to firms in other sectors or to the self-employed, which are then more likely to generate precarious job conditions. These substitution efforts will reduce in-house training activities and further contribute to the risks of a dual labour market (OECD, 2008a, 2006 and 2012g). An extensive evaluation study commissioned by the German Ministry of Labour in 2011 covering all sectors with minimum wages failed to find any substantial negative effects on employment and market entry in the sectors concerned. However, employment losses may have resulted due to indirect effects on other sectors (van Suntum, 2014).

27. The government plans to phase in a general minimum wage of EUR 8.50 between 2015 and the end of 2016 and to create a commission to propose future adjustments of the general minimum wage. The members of the commission will be nominated by social partners, with the possibility to consult independent experts, who will have no voting power. Sectoral minimum wages above the general minimum wage will continue to apply and the government plans to make it easier to legally extend collectively bargained sectoral minimum wages above the general minimum wage. At present, several of these sectoral minimum wages are higher than EUR 8.50.

28. The government's plans to introduce a general minimum wage are welcome. However it should be ensured that the initial level does not entail considerable negative employment effects. A minimum wage of EUR 8.50 would amount to about half of the median wage, placing the German minimum wage at a level similar to those of other European countries, such as Belgium and the Netherlands, but below France. It would affect about $15 \%$ of employees nation-wide and more than $23 \%$ in Eastern Germany. It may harm the employment prospects of workers in some regions and with little experience or low skills (Brenke, 2014). A useful strategy would be to introduce the minimum wage at a lower level and make adjustments in the light of its impact, as was done in the United Kingdom. The mandate of the expert commission should be to set the minimum wage at a level which balances potential employment losses against the social benefits. The social partners alone may not sufficiently take the interests of the unemployed into account. It could therefore be desirable to involve independent experts or government representatives in the commission's decisions. Moreover, given the introduction of the nationwide minimum wage, cautious use should be made of higher sectoral minimum wages set on the basis of collective agreements.

\section{Active labour market policies and in-work benefits could be improved}

29. Total spending on ALMPs is relatively high (Figure 9) and spending per unemployed has increased by almost $50 \%$ since 2007. Spending increased particularly for training and integrating the disabled, in line with recommendations in the 2012 Economic Survey of Germany. However, spending per unemployed on public employment services increased sharply as well and is now unusually high. While in many cases ALMPs are found to be counterproductive, i.e. rather extending the time of unemployment (Federal Government, 2006), placement services and hiring subsidies are found to be particularly effective in the short-term, whereas instruments aiming at improving education outcomes take more time to unfold their effects but are considered to be more beneficial in the long-term (Kluve, 2013). 
Figure 9. Spending on labour market programmes ${ }^{1}$

USD thousands at PPP per unemployed person, 2011

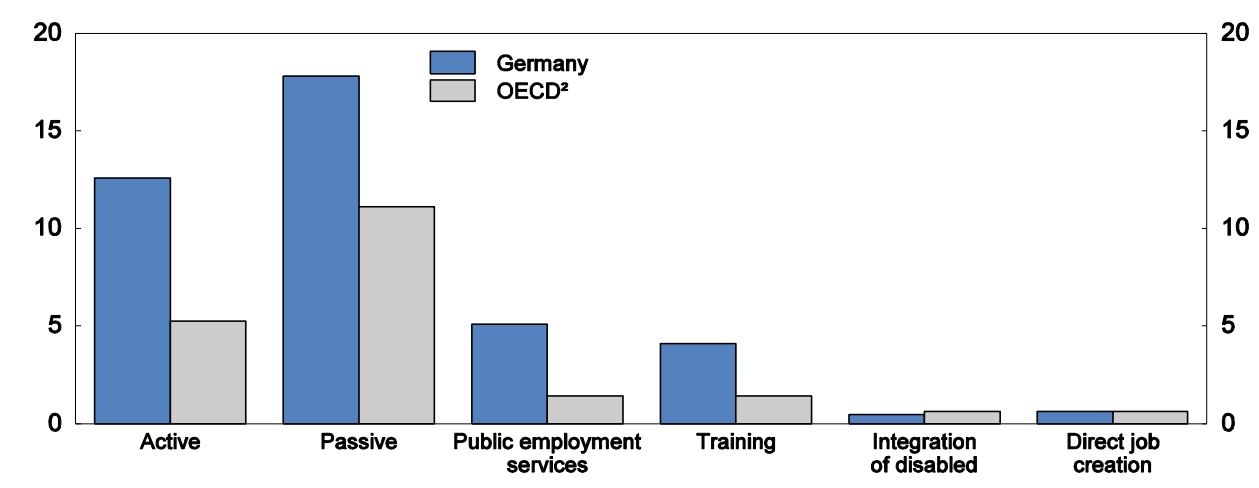

1. Spending per unemployed person for a country is adjusted for national income by multiplying this number by the ratio of US over each country's GDP per capita.

2. 28 OECD countries available for 2011 , except Greece, Iceland, Ireland, Norway, Turkey and the United Kingdom.

Source: OECD Labour Market Programmes database, OECD National Account database and OECD Economic Outlook database.

30. Many ALMPs benefit mostly those with a comparatively strong socio-economic background within their respective target groups. Vouchers - including for education and private job placement services - as well as hiring subsidies are more often taken up and actually used by individuals with a comparatively strong socio-economic background. Self-selection effects within target groups may persist, in part because better educated individuals are often better informed and less discouraged (Heyer et al., 2011).

31. Hiring subsidies (Eingliederungszuschuss), which are considered to be effective in bringing longterm unemployed and migrants back to work, could be targeted more towards the neediest (Butschek and Walter, 2013; Heyer et al., 2011). For example hiring subsidies could become more generous for the most disadvantaged individuals with the longest unemployment spells. Hiring subsidies could be accompanied to a larger extent by incentives to achieve higher general education to ensure a lasting integration of disadvantaged individuals in the labour market and increase income mobility (Kluve, 2013).

32. Steps have been taken to raise the incentives of public employment service offices to direct efforts more towards bringing the most disadvantaged individuals into work in 2014, including the long-term unemployed and low skilled. These steps are welcome. However, continued assistance and guidance following placement, during the initial period in work, is also needed to ensure lasting integration into the labour market. Also incentives of providers of private job placement services should be reviewed, as these vouchers benefit mostly job searchers with relatively high employability (Heyer et al., 2011).

33. There is scope to further review in-work benefits to ensure that the most vulnerable receive sufficient support while minimising disincentives to work. For instance, means-tested subsistence benefits are currently phased out as earnings rise above EUR 100. While the phasing out is already slower for families with children, the benefits could be phased out more slowly for particularly vulnerable individuals, such as single parents (Meister, 2009). Child benefits paid to parents receiving a housing allowance could also be phased out more slowly to remove disincentives to work. Currently they are discontinued abruptly at a certain income level. 
ECO/WKP(2014)71

\section{The education system could provide more support for the disadvantaged}

34. PISA results in Germany have improved in all three PISA domains and are now above the OECD average. These improvements were mostly due to better results among students coming from a lower socio-economic or immigrant background (OECD, 2013i and 2014). However, the link between socioeconomic background and mathematics performance remains strong compared to the OECD average and immigrants remain more disadvantaged than nationals (Figure 10). A strong link between socioeconomic background and learning outcomes undermines employment prospects and income mobility of the most vulnerable.

Figure 10. Impact of socio-economic status on the average difference in performance in mathematics ${ }^{1}$

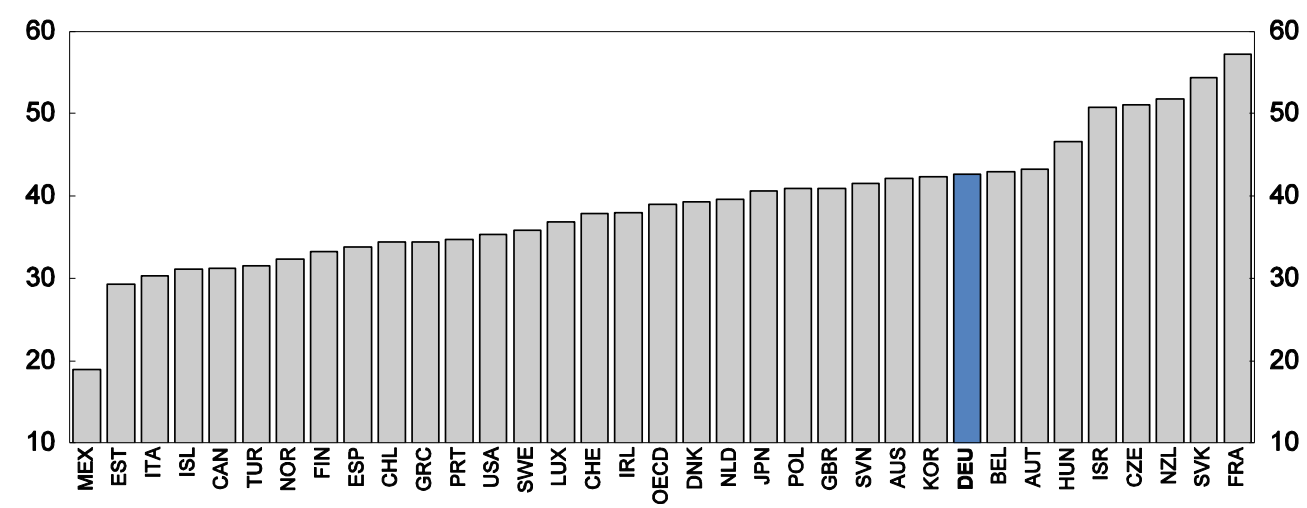

1. The average difference in mathematics score between students whose socio-economic status differs by one unit of the PISA index of economic, social and cultural status. The lower the value the smaller the difference (or the more equal performance between advantaged and disadvantaged students).

Source: OECD (2013), PISA 2012 Results: Excellence through Equity, Giving Every Student the Chance to Succeed, Vol. II, preliminary version.

\section{Reviewing system level policies}

35. Further reforms are needed to improve learning outcomes and facilitate access to upper secondary and tertiary education among disadvantaged youth. Performance variation between schools is relatively large, reflecting in large part stratification of the school system (OECD, 2012c) and a high share of disadvantaged students going to disadvantaged schools (OECD, 2013i). Efforts should be made to continue to reduce stratification of the school system as recommended in the 2008 Economic Survey of Germany. Also, grade repetition, which is particularly widespread in Germany, should be reduced. It widens inequity, increases the likelihood of dropping out and does not improve education outcomes (OECD, 2012c). Moreover, grade repetition raises total expenditure on primary and secondary education by $7 \%$. Moreover, efforts should continue to remove financial barriers to access to tertiary education. The main federal means-tested student support scheme provides grants and loans with income contingent repayments of up to EUR 8040 per year for needy students. However, consideration should be given to raising the maximum amount of support and to making all loan repayments contingent. While an additional preferential student loan scheme provides loans of up to EUR 7200 per year, their repayment is not contingent on income.

36. A relatively large share of pupils with learning difficulties is separated from the mainstream and placed in classes or schools for children with learning difficulties or disabilities (Figure 11, top panel; OECD, 2012c). Pupils are more likely to be assigned to such special needs schools if their socio-economic background is disadvantaged. For example, children with migrant background are overrepresented in 
special needs schools. Also, the share of pupils in special needs schools varies considerably across Länder (Figure 11, bottom panel). Assignment of pupils to special needs schools undermines their career prospects early on, as many of them leave school without having completed even lower secondary education. Instead, integrating children with learning difficulties in mainstream classes and schools raises their education outcomes and is less costly (OECD, 2009). In this context, the initiative by the Länder to promote integrated education is welcome (Kultusministerkonferenz, 2010). A coherent strategy should be developed for integrated education across Länder, limiting assignment of children to separate special needs education, and avoiding that children with disadvantaged socio-economic background are assigned to them on account of their weak socio-economic status.

\section{Figure 11. Special education needs}

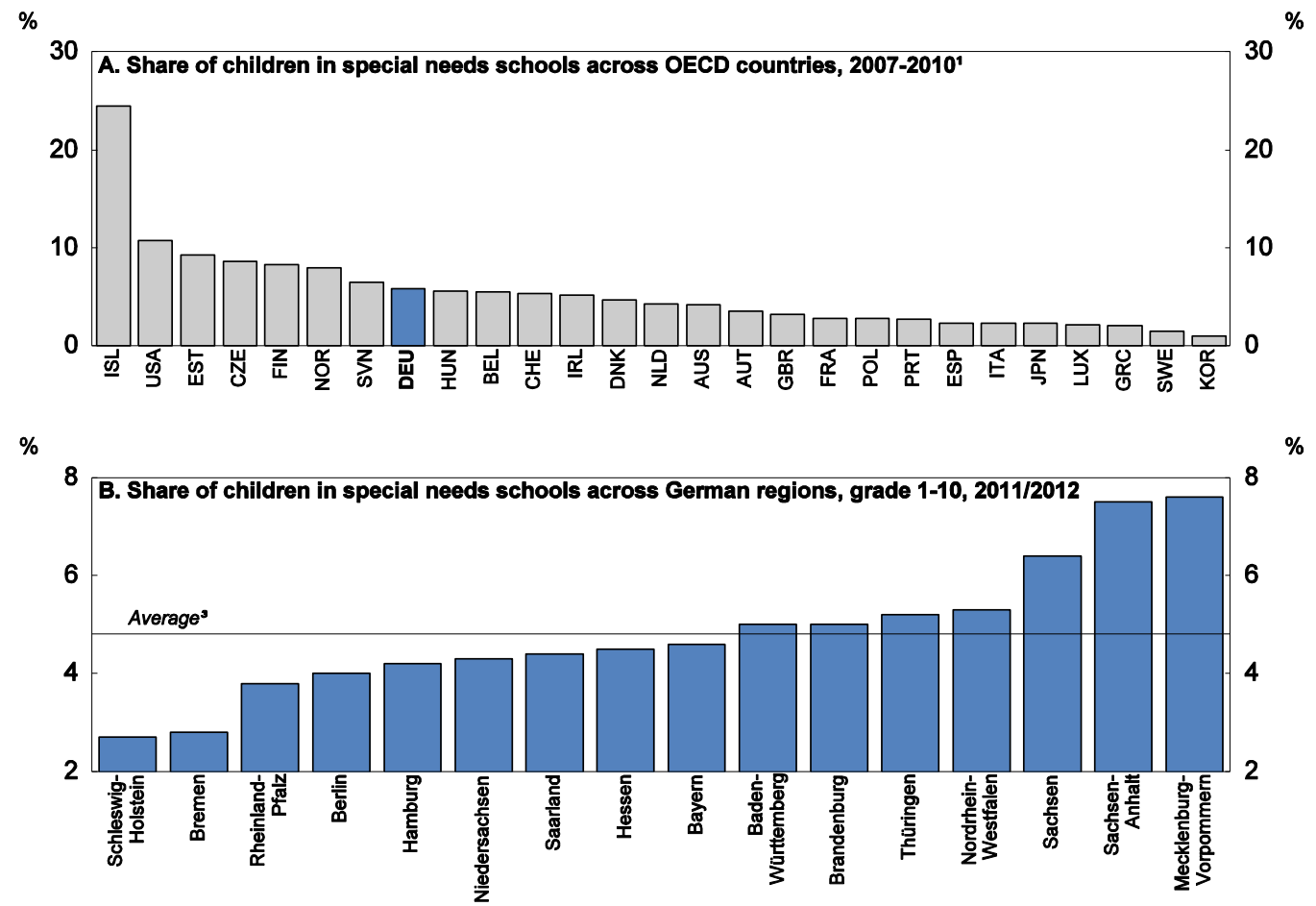

1. Academic school year 2007/2008 for Germany, Portugal and Spain; 2008/2009 for Austria, Belgium, Denmark, Finland, France, Hungary, Iceland, Ireland, Italy, Luxembourg, Sweden, Switzerland, the United Kingdom and the United States; 2009/2010 for Australia, Czech Republic, Estonia, Greece, Japan, Korea, Netherlands, Norway, Poland and Slovenia.

2. Unweighted average of sixteen German regions.

Source: OECD Family database; and Berkemeyer (2013), "Chancenspiegel 2013 - Zur Chancengerechtigkeit und Leistungsfähigkeit der deutschen Schulsysteme mit einer Vertiefung zum schulischen Ganztag", Bertelsmann Stiftung.

37. Most young people who do not obtain at least upper secondary education face a high risk of unemployment or, if in employment, low wages (OECD, 2013b). In Germany, 10.6\% of youth aged 18-24 have at most lower secondary education and are not in education or training, many of them with migrant background, according to Eurostat; about $8 \%$ do not complete lower secondary education. While special training measures exist to integrate these youth into vocational education and training (VET), they are often not successful. Around 260000 youth ( $26 \%$ of all youth entering VET per year) attended special training programmes in 2012 (Federal Statistical Office of Germany, 2014). Half of them are expected to not successfully complete formal VET (Authoring Group Educational Reporting, 2013; Klemm, 2012). Against this backdrop greater efforts are needed to help early school leavers to achieve at least upper secondary education. Guaranteeing direct access to VET to all school leavers, an idea also spelled out in 
the 2013 coalition agreement, would require additional resources of about EUR 1.5 billion per year, according to Klemm (2012). However, this cost is likely to be partially recovered through higher tax revenues in the long-term. To achieve this goal, existing training programmes need to be tailored more towards bringing youth quickly into mainstream VET programmes in close cooperation with private companies (Plicht, 2010). The federal government and governments of the Länder are setting up a programme (education chains) to streamline the existing initiatives in vocational orientation and to strengthen the transition from school into mainstream VET. In 2013 the Länder jointly made proposals to improve school-based training programs in the transition system. Some of these policies to make economic growth more socially inclusive also require additional public funding.

38. Efforts should also continue to raise the employability of older workers and immigrants. Lifelong learning can help to improve employability among experienced workers, thereby reducing poverty risks as suggested in the 2012 Economic Survey of Germany. Specialisation early on should be avoided as older workers, who face a high risk of long-term unemployment (Figure 5), are particularly vulnerable to structural changes. Despite recent reforms, difficulties in the recognition of professional and vocational qualifications obtained abroad hold back earnings prospects of immigrants. The Federal Recognition Act, in force since April 2012, has proved effective. The first data show that in most cases the equivalence of foreign professional qualifications was established and the recognition was granted. However, differences continue to exist in the recognition of foreign credentials across Länder. This limits the capacity of immigrants to move to locations where their skills are in highest demand (OECD, 2013e). The recognition of professional and vocational qualifications should be furthered facilitated, as planned by the government, and harmonized across Länder.

\section{Providing more targeted support to disadvantaged pupils}

39. The share of public spending on compulsory schooling directed to children of low-income families is lower than in most other OECD countries (Verbist et al., 2012). As in many OECD countries, there is scope to provide more financial resources to schools with a comparatively high share of pupils with weak socio-economic background (OECD, 2012c). For instance, considerable differences exist in spending per pupil across school tracks with spending per pupil being lower in middle schools (Realschule) than in high schools (Gymnasium). Also modern secondary schools (Hauptschulen) have difficulties in attracting qualified teachers (Authoring Group Educational Reporting, 2013), indicating that their employment conditions need to be improved. More financial and career incentives should be provided to attract and retain high quality teachers and leaders in schools attended by disadvantaged children also with regard to the large share of older teachers currently on active duty (OECD, 2014). It should be ensured that teachers earn the same across different school tracks. To address learning gaps and avoid grade repetition, which is relatively high, it should be ensured that an adequate environment for learning is made available to the most disadvantaged children, including for counselling, mentoring and smoothing transitions between the different levels of education (OECD, 2012c).

40. To further increase the benefits of existing early childhood education and care additional resources should be made available: to increase the staff-child ratio; to provide more integrated education and care; and to ensure early childhood professionals (e.g. educators, pedagogues, etc.) have better qualifications, more professional development opportunities and better working conditions, as planned by the government (OECD, 2012e; Federal Ministry for Labour and Social Affairs, 2013). The Länder have developed a competence-oriented qualification profile for childcare workers in order to enhance and harmonize the quality of training programmes (Kultusministerkonferenz, 2011) and have made efforts to establish training courses at tertiary level. In the short term, however shortages of qualified staff need to be addressed.

41. The education package (Bildungspaket) is an initiative by the federal government to help children from poor households to participate in social activities and receive learning support. However, it may fail 
to reach the most vulnerable, despite means-testing, because of self-selection (Krug and Popp, 2008). Disadvantaged parents, including those with migrant background, are less likely to be aware of education support programmes for their children (Apel and Engels, 2012) and they tend to underestimate the longterm benefits of such activities. Therefore, continued effort is needed to ensure that the neediest children benefit from the programme, for example by continuing to tailor information and assistance towards these families. It should also be ensured that more funds are allocated to tutoring of disadvantaged children to improve their learning outcomes. Currently, this is only possible if a teacher certifies that a child is at risk of repeating a school year. Only $4 \%$ of children from families receiving subsistence payments or housing subsidies receive such support (Apel and Engels, 2012). Providing more funding for tutoring to disadvantaged children independently of whether they are at risk of repeating a school year could help them to perform better at school, which might encourage them to aim for higher education later on.

\section{Reforming health insurance to tackle inequalities}

42. The segmentation of health insurance into a private sector, which covers about $10 \%$ of the population, and a public sector, which covers the remaining 90\% (Box 5) raises efficiency concerns (OECD, 2008b; German Council of Economic Experts, 2006). Low and middle income earners and individuals with poorer health status are generally covered by public health insurance, where contributions are independent of health risks and proportional to wage income up to a ceiling. Employees with a wage income above EUR 53550 per year can opt out of public insurance and choose private insurance instead. High income earners with good health status have incentives to choose private insurance because insurance premia do not depend on income and because private insurers can adjust the terms of contracts they offer to new insurees in line with their perceived health risks. Moreover, private insurers do not participate in the central health fund, which redistributes insurance contributions of public insurers on the basis of riskadjusted transfers. The central health fund helps to avoid selection on the basis of risk (Box 3.5; OECD, 2008b). Private insurers can therefore compete on the basis of risk selection rather than on the basis of efficiency. Moreover, competition within the private insurance sector is de facto limited to attracting new entrants to the private system. New insurees can be selected on the basis of risk in most contracts, making individuals reluctant to switch, for example, after facing chronic conditions. Moreover, switching between private insurance providers is costly due to the restricted portability of ageing reserves (Box 5).

43. Private insurance can also result in poverty risks for some individuals when they experience a drop in income. These risks affect older workers, because insurance premia tend to increase with age and because they cannot return to the public insurance system. They also affect the self-employed, who do not generally have access to public insurance and may face high income uncertainty. It is therefore possible that the current health insurance system discourages risk-averse workers from becoming self-employed, especially if their business plans imply uncertain income prospects, as may particularly be the case for innovative start-ups. While special tariffs have to be provided by private health insurance companies for individuals who have difficulties in paying, they can be fairly expensive or provide only limited coverage (Box 5; Federal Ministry of Health, 2013a). While the dual health insurance system in Germany has a long tradition, it generates difficulties in today's labour market, in which employment histories often include changes in employment status and earnings. 
ECO/WKP(2014)71

\section{Box 5. The German health insurance system}

Healthcare coverage is provided through a mix of public health insurance, which covers about $90 \%$ of the population, and private health insurance for eligible individuals who opted out of the public system, including many civil servants.

Public health insurance: Employees with gross yearly earnings currently below EUR 53550 must be insured in the public health insurance system. Non-profit public insurers are funded mostly via the central health fund, which collects $15.5 \%$ of labour income from all insured (14.6 percentage points are equally shared by employer and employee and 0.9 percentage points are paid by the employee alone) and then distributes funds to insurers as riskadjusted transfers. Individual insurers compete mainly via additional lump-sum surcharges which they can levy on their clients (up to a limit of $2 \%$ of the income of the insured individual). The federal government contributed $7.4 \%$ to the central health fund's revenues in 2012 (Federal Ministry of Health, 2013a). Non-working spouses and children up to a certain age are insured at no extra cost if they have no income above EUR 395 (or EUR 450 out of a minijob). Public insurers are subject to the obligation to accept every individual fulfilling the criteria for access to the public scheme and wishing to conclude a contract with them and cannot vary premia according to individual risk. The 2013 coalition agreement stipulates abolishing the lump sum surcharges which can be levied by individual insurers, replacing them by income dependent surcharges to be paid by the employee.

Private health insurance: Employees with gross yearly earnings currently exceeding EUR 53550 can opt out of the public health insurance scheme. The self-employed must insure themselves in the private sector unless they were insured in the public sector before becoming self-employed, in which case they can choose between public and private insurance. Civil servants are reimbursed $50 \%$ of their healthcare costs by their employers if they take out private insurance. Premia do not depend on income and, in general, insurers can charge higher fees to new clients depending on their perceived health risks. Private health insurance companies are obliged to build up old age reserves for their clients, which are in principle portable if switching between private health insurance providers (Commonwealth Fund, 2012). However, switching between private insurance providers is costly because the scope of portable ageing reserves is restricted to that of the basic tariff and to insurees who joined private health insurance after 2008. Therefore, in practice competition among private health insurance companies is limited to attracting new entrants to the private system.

Private insurers are obliged to offer special tariffs for individuals having difficulties in paying for their health insurance. The basic and the standard tariff provide coverage comparable to the one of public insurance, but these tariffs cost up to EUR 610 per month in 2013 regardless of income. Income support is provided by the government only if the privately insured's income risks falling below the subsistence threshold. For individuals who fall behind with their contribution payments, an emergency tariff (Notlagentarif) was introduced in 2013 with a premium not higher than EUR 125. However, it provides considerably less coverage than public insurance (Federal Ministry of Health, 2013b).

The transition from private health insurance back to public health insurance is only possible under certain, narrow circumstances. Employees whose income falls below the income threshold can switch to the public system if they are less than 55 years old. In principle switching is not possible for the self-employed.

44. The German Council of Economic Experts (2006) and the 2008 OECD Economic Survey of Germany therefore suggested integrating private health insurance providers in the central health fund. The German Council of Economic Experts also suggested imposing the obligation to contract on all insurers and limiting the cost of mandatory health insurance for low-income households with government transfers. This would imply that all insurance companies provide mandatory health insurance packages to all individuals on equal terms, as public insurance companies already do. Such a reform would remove incentives for risk selection and reduce poverty risks. However, it would give rise to substantial transitory challenges. In particular, it requires dealing with the reserves accumulated in the private health insurance system.

45. While the introduction of the central health fund (see Box 5) has raised efficiency and transparency, it should be developed further (Drösler et al., 2011). As only a limited number of 80 diseases are considered to determine risk-adjusted transfers, public health insurance companies continue to have 
incentives to discriminate against clients with diseases not included in the adjustment, for example including some forms of mental ill health. Despite an obligation to contract, public insurance companies can influence their client structure to some extent, for instance by advertising their services to selected groups. Therefore, the current risk-adjustment should be reviewed and include a larger number of diseases.

46. Unlike in other countries with central health funds, the treatment costs of deceased individuals are not annualized when determining disease specific transfers. For higher age groups and diseases with high death tolls costs are systematically underestimated and thus transfers from the central health fund too low (Buchner et al., 2012). It should be ensured that risk-adjusted transfers are set high enough for clients with cost-intensive diseases characterized by high morbidity as also spelled out in the 2013 coalition agreement.

\section{Limiting the risk of rising old age poverty}

47. Although old age poverty is not a major concern in Germany today, this is expected to change as population ageing and past pension reforms will reduce the level of pensions in the public system relative to income earned during active life (German Council of Economic Experts, 2013). Net pension replacement rates for future retirees are among the lowest across OECD countries, especially for workers earning half the average wage and retiring after a full career (OECD, 2013h). One reason is that pension claims are more closely related to income than in most other OECD countries. In this context, the rise of low pay-jobs, low wage mobility and emerging labour market dualisation aggravate risks of old-age poverty. Helping workers to acquire sufficient pension claims over their working life by improving earnings prospects of workers subject to low-pay and part-time work is the best way to tackle the risk of old age poverty. In this context labour market reforms to boost permanent full-time employment as outlined above are particularly helpful.

48. The 2013 coalition agreement includes several measures to extend pension claims for selected groups. Workers with a contribution record of at least 45 years will be able to retire with a full pension at age 63 initially, rising to 65 years, in line with the increase of the standard legal pension age from 65 to 67 years. If implemented, they provide an incentive to retire earlier. Pension top-ups will also be paid to mothers whose children were born before 1992 and invalidity pensions will be raised. In the medium term, these measures will be funded by payroll contributions, which are projected to be 0.4 percentage points higher as a result of the planned measures by 2030. There are also plans to implement a minimum pension for people with a contribution record of at least 40 years and low pension entitlements at a later stage. The plans are not specifically targeted at addressing old-age poverty, which could become a problem in decades to come, and thus may generate more spending pressures in the future. If pension entitlements for workers with a low earnings record are deemed too low, a cost effective way of raising incomes for pensioners with low entitlements while safeguarding incentives to work would be to phase out means-tested subsistence benefits more slowly as pension entitlements rise.

49. The mandatory public pension system generally covers employees only. Only about one quarter of the self-employed, mainly in professional services, are covered by alternative mandatory pension schemes (German Council of Economic Experts, 2011). The remaining self-employed workers, often including the most vulnerable, are not covered (German Council of Economic Experts, 2013). They may not sufficiently price in future pension requirements to offer their goods and services at a low price. This creates a coverage gap raising the risk that self-employed workers have to rely on social assistance benefits during retirement. Firms have incentives to outsource work to these self-employed workers at low cost in order to avoid pension contributions, raising precarious self-employment and weakening government finances. Against this backdrop, all self-employed should be included in the mandatory public pension scheme. 
ECO/WKP(2014)71

\section{Making the tax system more inclusive}

50. The labour tax wedge is high in international comparison, including for low income families and single parents (Table 4). While income tax rates are low, especially for families with children, social security contributions are high.

Table 4. Tax wedge by family type and wage level

\% of gross wage earnings, 2012

\begin{tabular}{|c|c|c|c|c|c|c|c|c|c|}
\hline Family type & & single & single & single & single & married & married & married & married \\
\hline Children & & no & no & no & 2 & 2 & 2 & 2 & no \\
\hline$\%$ of average wage & & 67 & 100 & 167 & 67 & $100-0^{*}$ & $100-33^{*}$ & $100-67^{*}$ & $100-33^{*}$ \\
\hline \multirow{2}{*}{ Income tax } & DEU & 14.2 & 19.2 & 27.8 & -2.5 & 0.8 & 6.5 & 10.8 & 14.2 \\
\hline & OECD & 11.2 & 15.3 & 21.3 & 5.9 & 9.9 & 10.4 & 12.2 & 12.3 \\
\hline \multirow{2}{*}{$\begin{array}{l}\text { Employee soc sec } \\
\text { contributions }\end{array}$} & DEU & 20.7 & 20.7 & 16.0 & 20.5 & 20.5 & 20.5 & 20.5 & 20.7 \\
\hline & OECD & 9.9 & 9.8 & 9.2 & 9.5 & 9.7 & 9.5 & 9.8 & 9.6 \\
\hline \multirow{2}{*}{$\begin{array}{l}\text { Employer soc sec } \\
\text { contributions }\end{array}$} & DEU & 19.6 & 19.6 & 15.3 & 19.6 & 19.6 & 19.6 & 19.6 & 19.6 \\
\hline & OECD & 17.5 & 17.8 & 17.2 & 17.5 & 17.8 & 17.4 & 17.7 & 17.4 \\
\hline \multirow{2}{*}{ Total } & DEU & 45.6 & 49.8 & 51.2 & 31.4 & 34.2 & 39.0 & 42.5 & 45.6 \\
\hline & OECD & 32.0 & 35.6 & 39.9 & 16.8 & 26.1 & 27.9 & 30.8 & 32.7 \\
\hline
\end{tabular}

* Two earner couple.

Source: OECD Taxing Wages.

51. Lowering social security contributions, notably for low income workers with full-time earnings, should be a priority. Such a step should be placed in the context of a broader reform to make the tax system more conducive to economic growth. In particular this involves continued efforts to reduce the tax burden on labour income, especially for workers on low pay. Such a reform should also include measures on the expenditure side of the social security system. More revenues could be raised from taxes on consumption, real estate and environmentally harmful behaviour, as suggested in the 2012 Economic Survey of Germany.

52. Some sources of capital income benefit from preferential tax treatment. Households' capital income (interest payments, dividends) is generally taxed at a rate of $26.4 \%$ at the household level, although households' interest income benefits from a tax-free allowance up to EUR 801. The general tax rate for capital income is, in many cases, below the marginal income tax households pay on their other income, as capital income is particularly concentrated among high-income households. These reduced tax rates have in the past helped to reduce tax evasion through capital flight. However, efforts have been made to improve international cooperation to prevent tax fraud. A moderate increase in capital income taxation may therefore not lead to more tax evasion (Bach and Beznoska, 2012b). Consideration should be given to align the taxation of capital income to the taxation of other personal income. Moreover, households are fully exempt from capital gains tax on housing property, held for more than 10 years, even if the owner does not live in the dwelling concerned. This tax exemption risks biasing investment decision towards residential housing, especially in the current low interest rate environment which may encourage expectations of rising prices and benefits high-wealth households the most (Frick and Grabka, 2009; Deutsche Bundesbank, 2013; European Central Bank, 2013). Realised capital gains on housing should be taxed, except for owner-occupied housing.

53. Inheritance taxes have less distortionary effects and entail a lower administrative burden than other forms of taxation of wealth (Bach and Beznoska, 2012a). There is scope to further increase revenues from inheritance taxes by removing exemptions. Wealth held in small and medium sized enterprises is 
subject to lower inheritance taxation than other forms of wealth under certain conditions. Households therefore have incentives to transform private into business property to lower their tax burden (Bach and Beznoska, 2012b). The conditions for such transformations have recently been tightened. The remaining tax advantages provided to small firms in inheritance taxation should be reconsidered. To avoid liquidity problems for businesses subject to inheritance tax, tax payments can already be stretched over ten years. During this period, the tax liability could be subordinated to other claims on the business (see e.g. the 2004 Economic Survey of Germany).

\section{Regional pockets of poverty risk could be addressed more effectively}

54. Although dispersion of GDP per capita across Länder continued to decline over the past decade and is now lower in Germany than in most other EU countries, the risk of relative poverty has risen to a considerably higher level in East than in West Germany and continues to diverge (Grabka et al., 2012).

55. The current revenue-sharing system including fiscal federal transfers is based on population as well as on multipliers which only reflect differences in population density (Söllner, 2001). Although, additional discretionary transfers exist, in part to account for differences in long-term unemployment rates, they do not take into account additional socioeconomic and demographic characteristics, such as migrant status, or age composition, in the population structure across the Länder, which contribute to different levels of demand for public services provided by Länder and municipalities on their territory (Feld et al., 2013; Heinemann, 2012). It should be considered to enlarge the set of criteria based on which transfers are provided, e.g. by including differences in age composition, socio-economic or migrant background. The advantage of including such demographic indicators in the determination of fiscal federal transfers is that they can help align such transfers with demand for social services more effectively without harming incentives of the poorest jurisdictions to strengthen their growth potential (Joumard and Kongsrud, 2003).

56. Subnational government levels may also face disincentives to provide adequate provision for key services that can help to boost inclusive economic growth. For example, municipalities may not fully take into account the benefits provided by childcare facilities and early childhood education, for which they have funding responsibilities, because they partly accrue to neighbouring jurisdictions or even nation-wide. Special grants from state to local governments are available to address such externalities. However they are provided on a discretionary basis with rules (for local grants) differing considerably across the Länder (Dombert, 2006). The government should consider assuming funding responsibilities for key social services provided by subnational governments subject to geographic externalities, which are particularly important for inclusive growth. For example, the federal government could finance vouchers for families with young children which they could use to pay for the services of accredited childcare facilities. 


\section{Box 6. Recommendations to foster inclusive growth}

\section{Labour market}

- Continue to expand early childcare provision, notably for full-day care. Ensure equal access of the most vulnerable to affordable high-quality childcare independently of their place of residence and socio-economic background. Extend the supply of all-day schools.

- $\quad$ Reduce the gap in employment protection between permanent and temporary workers by reducing protection of permanent workers and by limiting the use of multiple successive fixed term contracts with the same employee.

- Introduce a general minimum wage at a sufficiently low level that will not lead to job losses, determined by an expert commission. Cautious use should be made of higher sectoral minimum wages set on the basis of collective agreements.

- $\quad$ Target the preferential tax treatment of minijobs towards low-wage workers.

- Make active labour market policies more targeted by monitoring self-selection problems within target groups. Continue to review in-work benefits to ensure that the most vulnerable receive sufficient support while minimising disincentives to work. For instance, phase out more slowly means-tested subsistence benefits for particularly vulnerable individuals earning more than EUR 100. Also phase out additional child benefits paid to parents receiving a housing allowance more slowly.

\section{Education}

- Reduce stratification of the school system and provide more financial resources to schools with a comparatively high share of pupils with weak socio-economic background. Reduce grade repetitions. Provide more support for disadvantaged youth to complete formal upper secondary education programmes, in particular mainstream VET. Continue reducing the assignment of pupils to special needs schools and make sure assignment to such schools does not reflect the socio-economic background of pupils.

- Improve the quality of early childhood education and care, including by improving the staff-child ratio in accredited facilities; by better integrating education and care; and by ensuring early childhood professionals have better qualifications, more professional development opportunities and better working conditions.

\section{Tax and transfer system}

- $\quad$ Extend compulsory pensions to the self-employed.

- $\quad$ Focus additional pension entitlements on reducing future old age poverty risks, for example, by phasing out subsistence benefit entitlements more slowly as pension entitlements rise.

- Fund such additional spending from general tax revenue instead of higher payroll taxes. Strengthen incentives to retire later.

- Extend capital gains taxes on residential real estate except for owner-occupied housing. Raise the tax rates applying to household capital income towards marginal income tax rates applying to other household income.

- $\quad$ Equalize the inheritance tax burden for different forms of wealth.

- $\quad$ Further improve the determination of risk-adjusted transfers within the health fund, by considering a larger number of diseases and by ensuring that transfers for higher age groups and diseases with high death tolls are high enough. 


\section{BIBLIOGRAPHY}

Acemoglu, D. and J.S. Pischke (2001), "Minimum Wages and On- the-Job Training”, IZA Discussion Papers Series No. 384.

Adema, W., P. Fron and M. Ladaique (2011), "Is the European Welfare State Really More Expensive? Indicators on Social Spending, 1980-2012; and a Manual to the OECD Social Expenditure Database (SOCX)", Social, Employment and Migration Working Papers No. 124, OECD Publishing, Paris.

Andrews, D. and A. Caldera Sánchez (2011), "The Evolution of Homeownership Rates in Selected OECD Countries: Demographic and Public Policy Influences”, Economic Studies Vol. 2011/1, OECD Publishing, Paris.

Apel, H. and D. Engels (2012), "Bildung und Teilhabe von Kindern und Jugendlichen im unteren Einkommensbereich. Untersuchung der Implementationsphase des Bildungs- und Teilhabepakets”, im Auftrag des Bundesministeriums für Arbeit und Soziales, Berlin.

Aretz, B. (2013), "Gender Differences in German Wage Mobility”, ZEW Discussion Papers No. 13-003.

Authoring Group Educational Reporting. (2013) Bildung in Deutschland 2012, Autorengruppe Bildungsberichterstattung, Bielefeld.

Bach, S. and M. Beznoska (2012a), "Vermögensteuer: Erhebliches Aufkommenspotential trotz erwartbarer Ausweichreaktionen, DIW Wochenbericht No. 42.

Bach, S. and M. Beznoska (2012b), “Aufkommens- und Verteilungswirkungen einer Wiederbelebung der Vermögensteuer”, Politikberatung kompakt No. 68, DIW Berlin.

Blossfeld, H.P. et al. (2013), Zwischenbilanz Ganztagsgrundschulen: Betreuung oder Rhythmisierung?, Aktionsrat Bildung, Vereinigung der Bayerischen Wirtschaft.

Brenke, K. (2014), “Zahl der anspruchsberechtigten Arbeitnehmer wird weit unter fünf Millionen liegen ”, DIW Wochenbericht No. 5.2014.

Bruckmeier, K. et al. (2013), “Aufstocker im SGB II Steinig und lang - der Weg aus dem Leistungsbezug", IAB Kurzbericht No. 14/2013.

Bryan M., A. A. Salvatori and M. Taylor (2012), The Impact of the National Minimum Wage on Earnings, Employment and Hours through the Recession, a report to the Low Pay Commission, University of Essex.

Buchner, F., D. Goepffarth and J. Wasem (2012), “The new risk adjustment formula in Germany: Implementation and first experiences", Health Policy No. 109, pp. 253-262.

Butschek S. and T. Walter (2013), "What Active Labour Market Programmes Work for Immigrants in Europe? A Meta-Analysis of the Evaluation Literature", ZEW Discussion Papers No. 13-056.

Card, D. and A.B. Krueger (1995), Myth and Measurement: The New Economics of the Minimum Wage, Princeton University Press. 
Commonwealth Fund (2012), International Profiles of Health Care Systems, 2012, November, New York, NJ.

D’Amuri, F., G. Ottaviano and G. Peri (2010), “The Labour Market Impact of Immigration in Western Germany in the 1990s", European Economic Review Vol. 54, No. 4, pp. 550-570.

de Serres, A., F. Murtin and C. de la Maisonneuve (2012), "Policies to Facilitate the Return to Work", Comparative Economic Studies Vol. 54, Issue 1, pp. 5-42, OECD Publishing, Paris.

Deutsche Bundesbank (2013), Private Haushalte und ihre Finanzen - Tabellenanhang zur Pressenotiz vom 21.3.2013, February.

Dombert, M. (2006), “Zur finanziellen Mindestausstattung von Kommunen”, Deutsches Verwaltungsblatt No. 18, pp. 1136-1143.

Drösler, S. et al. (2011), Evaluationsbericht zum Jahresausgleich 2009 im Risikostrukturausgleich, 22.09.2011, Ministry of Health, Berlin.

Dustmann, C., J. Ludsteck and U. Schönberg (2009), "Revisiting the German Wage Structure", Quarterly Journal of Economics Vol. 124, No. 2, pp. 843-881, MIT Press.

Eichhorst, W. and V. Tobsch (2013), "Has atypical work become typical in Germany? Country case study on labour market segmentation”, ILO Employment Working Papers No. 145.

European Central Bank (2013), The Eurosystem Household Finance and Consumption Survey - Statistical Tables, April.

European Court of Justice (2012), “Case C-586/10 Bianca Kücük v Land Nordrhein-Westfalen”, Judgment of the Court (Second Chamber), 26 January 2012, Luxembourg.

Federal Government (2006), Die Wirksamkeit moderner Dienstleistungen am Arbeitsmarkt, Bericht 2005 der Bundesregierung zur Wirksamkeit moderner Dienstleistungen am Arbeitsmarkt, BundestagsDrucksache 16/505, 01.02.2006.

Federal Ministry for Labour and Social Affairs (2013), Lebenslagen in Deutschland - Vierter Armuts- und Reichtumsbericht der Bundesregierung, Ministry for Labour and Social Affairs, Berlin.

Federal Ministry of Finance (2012), Alleinerziehende in Deutschland - Lebenssituationen und Lebenswirklichkeiten von Müttern und Kindern Monitor Familienforschung Beiträge aus Forschung, Statistik und Familienpolitik, Ministry of Finance, Berlin.

Federal Ministry of Health (2013a), Gesetzliche Krankenversicherung - Kennzahlen und Faustformeln, Ministry of Health, Berlin.

Federal Ministry of Health (2013b), "Gesetz zur Beseitigung sozialer Überforderung bei Beitragsschulden in der Krankenversicherung tritt am 1. August in Kraft", Pressemitteilung No. 59, Ministry of Health, 30 Juli 2013.

Federal Statistical Office (2012), Kindertagesbetreuung in Deutschland 2012, Begleitmaterial zur Pressekonferenz am 6. November 2012 in Berlin. 
ECO/WKP(2014)71

Federal Statistical Office of Germany (2014), Integrierte Ausbildungsberichterstattung. Anfänger, Teilnehmer und Absolventen im Ausbildungsgeschehen nach Sektoren/Konten und Ländern 2012, Wiesbaden.

Feld, L., H. Kube and J. Schnellenbach (2013), Optionen für eine Reform des bundesdeutschen Finanzausgleichs, Gutachten im Auftrag der FDP Landtagsfraktionen der Länder BadenWürttemberg, Bayern und Hessen.

Fertig, M. and J. Kluve (2007), "Alternative Beschäftigungsformen in Deutschland: Effekte der Neuregelung von Zeitarbeit, Minijobs und Midijobs", Vierteljahrshefte zur Wirtschaftsforschung No. 75 , pp. 97-117.

Freier, R. and V. Steiner (2007), "Marginal Employment: Stepping Stone or Dead End? Evaluating the German Experience", DIW Diskussionspapers 744.

Frick, J.R. and M. Grabka (2009), "Gestiegene Vermögensungleichheit in Deutschland”, Wochenbericht des DIW Berlin No. 4/2009.

Garloff, A.A. (2010), "Minimum wages, wage dispersion and unemployment in search models. A review", ZAF No. 43, pp. 145-167.

Gathmann C. and B. Sass (2012), "Taxing Childcare: Effects on Family Labor Supply and Children”, IZA Discussion Paper Series No. 6440.

German Council of Economic Experts (2006), "Widerstreitende Interessen - Ungenutzte Chancen", Annual Economic Report 2006/7, Wiesbaden.

German Council of Economic Experts (2009), "Die Zukunft nicht aufs Spiel setzen”, Jahresgutachten, 2009/10, Wiesbaden.

German Council of Economic Experts (2011), "Verantwortung für Europa Wahrnehmen", Jahresgutachten, 2011/12, Wiesbaden.

German Council of Economic Experts (2013), "Gegen eine rückwärtsgewandte Wirtschaftspolitik", Jahresgutachten, 2013/14, Wiesbaden.

Grabka, M., J. Goebel and J. Schupp (2012), "Höhepunkt der Einkommensungleichheit in Deutschland überschritten?", Wochenbericht No. 43/2012.

Heckman, J.J. and D.V. Masterov (2007), "The productivity argument for investing in young children", NBER Working Papers No. 13016.

Heckman, J.J. and L.K. Raut (2013), "Intergenerational Long-term Effects of Preschool - Structural Estimates from a Discrete Dynamic Programming Model”, NBER Working Papers No. 19077.

Heinemann, A.W. (2012), “Horizontal oder vertikal? Zur Zukunft des Finanzausgleichs”, Wirtschaftsdienst No. 2012/7, ZBW-Leibniz-Informationszentrum Wirtschaft.

Heyer, G. et al. (2011), "Evaluation der aktiven Arbeitsmarktpolitik - Ein Sachstandsbericht für die Instrumentenreform 2011”, IAB Discussion Papers No. 17/2011. 
Hohendanner, C. and J. Stegmaier (2012), "Geringfügige Beschäftigung in deutschen Betrieben Umstrittene Minijobs", IAB Kurzbericht No. 24/2012.

Joumard, I. and P. M. Kongsrud (2003), "Fiscal Relations across Government Levels", Economics Department Working Papers No. 375, OECD Publishing, Paris.

Kierzenkowski, R. and I. Koske (2012), "Less Income Inequality and More Growth - Are they Compatible?", Part 8: "The Drivers of Labour Income Inequality - A Literature Review", Economics Department Working Papers No. 931, OECD Publishing, Paris.

Klemm, K. (2012), Was kostet eine Ausbildungsgarantie in Deutschland?, Bertelsmann Stiftung, Gütersloh.

Kluve, J. (2013), “Aktive Arbeitsmarktpolitik: Maßnahmen, Zielsetzungen, Wirkungen“, Arbeitspapier No. 07/2013, German Council of Economic Experts.

Koller L. and H. Rudolph (2011), “Arbeitsaufnahmen von SGB-II-Leistungsempfängern - Viele Jobs von kurzer Dauer”, IAB Kurzbericht No. 14/2011.

Körner,T., H. Meinken and K. Puch (2013), "Wer sind die ausschließlich geringfügig Beschäftigten? Eine Analyse nach sozialer Lebenslage", Wirtschaft und Statistik pp. 42-61, January 2013.

Koske, I., J. Fournier and I. Wanner (2012), "Less Income Inequality and More Growth - Are They Compatible?", Part 2: “The Distribution of Labour Income”, Economics Department Working Papers No. 925, OECD Publishing, Paris.

Krug, G. and S. Popp (2008), "Soziale Herkunft und Bildungsziele von Jugendlichen im Armutsbereich", IAB Discussion Papers No. 42/2008.

Kultusministerkonferenz (2010), Förderstrategie für leistungsschwächere Schülerinnen und Schüler 2010, Wolters Kluwer Deutschland GmbH, Köln.

Kultusministerkonferenz (2011), Kompetenzorientiertes Qualifikationsprofil für die Ausbildung von Erzieherinnen und Erziehern an Fachschulen/Fachakademien, Resolution 01/12/2011.

Meister, W. (2009), "Neuer Kinderzuschlag, Wohngeldreform, höhere Hartz-IV-Regelsatze: Insbesondere für Familien deutliche Einkommenssteigerungen”, ifo Schnelldienst No. 16/2009.

OECD (2004), Employment Outlook, OECD Publishing, Paris.

OECD (2006), Boosting Jobs and Incomes: Policy Lessons from Reassessing the OECD Jobs Strategy, OECD Publishing, Paris.

OECD (2008a), Growing Unequal? Income Distribution and Poverty in OECD Countries, OECD Publishing, Paris.

OECD (2008b), Economic Surveys: Germany, OECD Publishing, Paris.

OECD (2009), Economic Surveys: Switzerland, OECD Publishing, Paris.

OECD (2010), Economic Surveys: Germany, OECD Publishing, Paris. 
ECO/WKP(2014)71

OECD (2011), Divided We Stand - Why Inequality Keeps Rising, OECD Publishing, Paris.

OECD (2012a), Economic Surveys: Germany, OECD Publishing, Paris.

OECD (2012b), "Income inequality and growth: The role of taxes and transfers", Economics Department Policy Notes No. 9, OECD Publishing, Paris.

OECD (2012c), Equity and Quality in Education: Supporting Disadvantaged Students and Schools, OECD Publishing, Paris.

OECD (2012d), Income distribution data review - Germany, OECD Publishing, Paris.

OECD (2012e), Starting Strong III: A Quality Toolbox for Early Childhood Education and Care, OECD Publishing, Paris.

OECD (2012f), Settling In: OECD Indicators of Immigrant Integration, 2012, OECD Publishing, Paris.

OECD (2012g), Economic Policy Reforms 2012 Going for Growth, OECD Publishing, Paris.

OECD (2012h), Closing the Gender Gap - Act Now, OECD Publishing, Paris.

OECD (2013a), Crisis squeezes income and puts pressure on inequality and poverty - New Results from the OECD Income Distribution Database, OECD Publishing, Paris.

OECD (2013b), Employment Outlook, OECD Publishing, Paris.

OECD (2013c), Skills Outlook, OECD Publishing, Paris.

OECD (2013d), Education at a Glance, OECD Publishing, Paris.

OECD (2013e), Recruiting Immigrant Workers: Germany, OECD Publishing, Paris.

OECD (2013f), LMF1.5: Gender pay gaps for full-time workers and earnings differentials by educational attainment, OECD Publishing, Paris.

OECD (2013g), How's Life? 2013: Measuring Well-being, OECD Publishing, Paris.

OECD (2013h), Pensions at a Glance 2013: Retirement-Income Systems in OECD and G20 Countries, OECD Publishing, Paris.

OECD (2013i), PISA 2012 Results: Excellence through Equity (Volume II): Giving every Student the Chance to Succeed, OECD Publishing, Paris.

OECD (2014), Education Policy Outlook: Germany, OECD Publishing, Paris.

Peichl A., N. Pestel and H. Schneider (2010), "Does Size Matter? The Impact of Changes in Household Structure on Income Distribution in Germany", SOEPpapers No. 280.

Plicht H. (2010), "Das neue Fachkonzept berufsvorbereitender Bildungsmaßnahmen der BA in der Praxis Ergebnisse aus der Begleitforschung BvB", IAB Forschungsbericht No. 7/2010. 
Prasad, E.S. (2004), "The Unbearable Stability of the German Wage Structure: Evidence and Interpretation”, IMF Staff Papers Vol. 51, pp. 354-385.

Rainer, H. et al. (2011), "Kinderbetreuung”, ifo Forschungsberichte No. 59.

Rainer, H. et al. (2013), "Kindergeld und Kinderfreibeträge in Deutschland: Evaluierung der Auswirkungen auf familienpolitische Ziele", ifo Schnelldienst No. 9/2013.

Riphahn, R.T. and D. Schnitzlein (2011), "Wage Mobility in East and West Germany”, IZA Discussion Paper Series No. 6246.

Söllner, F. (2001), “Die Einwohnerveredelung im Länderfinanzausgleich”, ifo Schnelldienst No. 3/2001.

Spieß, C.K., E. Berger and O.Groh-Samberg (2008), "Overcoming Disparities and Expanding Access to Early Childhood Services in Germany: Policy Considerations and Funding Options", UNICEF Innocenti Research Centre Working Papers No. IWP-2008-03.

Spitz-Oener, A. (2006), "Technical Change, Job Tasks, and Rising Education Demand: Looking Outside the Wage Structure", Journal of Labour Economics Vol. 24, No. 2, pp. 235-270.

Steinhardt, M.F. (2011), “The Wage Impact of Immigration in Germany - New Evidence for Skill Groups and Occupations", The B.E. Journal of Economic Analysis and Policy Vol. 11, No. 1.

Van Suntum, U. (2014), "Indirekte Beschäftigungseffekte branchenspezifischer Mindestlöhne”, ifo Schnelldienst No. 67/03, pp. 39-44.

Verbist, G., M.F. Förster and M. Vaalavuo (2012), "The Impact of Publicly Provided Services on the Distribution of Resources: Review of New Results and Methods", Social, Employment and Migration Working Papers No. 130, OECD Publishing, Paris.

Voss, D. and C. Weinkopf (2012), “Niedriglohnfalle Minijob”, WSI Mitteilungen No. 1/2012.

Walwei, U. (2013), "Times of change: what drives the growth of work arrangements in Germany?", Journal for Labour Market Research, July.

Zabel, C. (2011), "Alleinerziehende ALG-II-Empfängerinnen mit kleinen Kindern. Oft in Ein-Euro-Jobs, selten in betrieblichen Maßnahmen", IAB Kurzbericht No. 21/2012. 
ECO/WKP(2014)71

\section{WORKING PAPERS}

The full series of Economics Department Working Papers can be consulted at www.oecd.org/eco/workingpapers

1174. New tax and expenditure elasticity estimates for EU budget surveillance (forthcoming)

1173. Moving towards a more dynamic business sector in Spain (November 2014) by Alberto Gonzalez Pandiella

1172. Better harnessing talent and knowledge to boost sustainable medium-growth in Spain (November 2014) by David Haugh and Ben Westmore

1171. The internet economy - regulatory challenges and practices

(November 2014) by Isabell Koske, Rosamaria Bitetti, Isabelle Wanner and Ewan Sutherland

1170. A revival of the private rental sector of the housing market? Lessons from Germany, Finland, the Czech Republic and the Netherlands

(October 2014) by Rik de Boer and Rosamaria Bitetti

1169. Secular stagnation: evidence and implications for economic policy

(October 2014) by Łukasz Rawdanowicz, Romain Bouis, Kei-Ichiro Inaba and

Ane Kathrine Christensen

1168. Investment gaps after the crisis

(October 2014) by Christine Lewis, Nigel Pain, Jan Strasky and Fusako Menkyna

1167. Factors behind the decline in real long-term government bond yield

(October 2014) by Romain Bouis, Kei-Ichiro Inaba, Łukasz Rawdanowicz and

Ane Kathrine Christensen

1166. The effect of the global financial crisis on the OECD potential output

(October 2014) by Patrice Ollivaud and David Turner

1165. Determinants of households' investment in energy efficiency and renewables - evidence from the OECD Survey on household environmental behaviour and attitudes

(October 2014) by Nadia Ameli and Nicola Brandt

1164. Addressing high household debt in Korea

(September 2014) by Randall S. Jones and Myungkyoo Kim

1163. Reducing the high rate of poverty among the elderly in Korea

(September 2014) by Randall S. Jones and Satoshi Urasawa

1162. Promoting the financing of SMEs and start-ups in Korea

(September 2014) by Randall S. Jones and Myungkyoo Kim

1161. Fostering inclusive growth by promoting structural change in the business sector (September 2014) by Rauf Gönenç, Oliver Röhn, Vincent Koen and Fethi Öğünç 
1160. Reducing macroeconomic imbalances in Turkey

(September 2014) by Oliver Röhn, Rauf Gönenç, Vincent Koen and Evren Erdoğan Coşar

1159. Reinvigorating the EU Single Market

(September 2014) by Jean-Marc Fournier.

1158. An exploration of the determinants of the subjective well-being of Americans during the great recession

(August 2014) by Aida Caldera Sánchez and Caroline Tassot.

1157. Boosting the development of efficient SMEs in the Netherlands

(September) by Rafał Kierzenkowski and Jochebed Kastaneer

1156. Making the banking sector more resilient and reducing household debt in the Netherlands

(September 2014) by Rafał Kierzenkowski, Olena Havrylchyk and Pierre Beynet

1155. US long term interest rates and capital flows to emerging economies

(July 2014) by Eduardo Olaberria

1154. Productivity measurement with natural capital and bad outputs

(July 2014) by Nicola Brandt, Paul Schreyer and Vera Zipperer

1153. Reducing income inequality and poverty and promoting social mobility in Korea

(July 2014) by Randall S. Jones and Satoshi Urasawa

1152. Fostering a creative economy to drive Korean growth

(July 2014) by Randall S. Jones and Myungkyoo Kim

1151. Economic uncertainties and their impact on activity in Greece compared with Ireland and Portugal

(July 2014) by Jan-David Schneider and Claude Giorno

1150. Workplace stress in the United States: issues and policies

(July 2014) by Michael Darden

1149. Taxing the rent of non-renewable resource sectors: a theoretical note

(July 2014) by Julien Daubanes and Saraly Andrade de Sá

1148. Health, work and working conditions: a review of the European economic literature

(July 2014) by Thomas Barnay

1147. Making the best of new energy resources in the United States

(July 2014) by Douglas Sutherland

1146. Improving well-being in the United States

(July 2014) by Aida Caldera Sánchez, Patrick Lenain and Sarah Fléche 